\title{
Recommended Tests for the Self-Disproportionation of Enantiomers (SDE) to Ensure Accurate Reporting of the Stereochemical Outcome of Enantioselective Reactions
}

\author{
Jianlin Han ${ }^{1}\left(\right.$ D , Alicja Wzorek ${ }^{2}$ (D), Karel D. Klika ${ }^{3, *}$ and Vadim A. Soloshonok ${ }^{4,5, *(D)}$ \\ 1 Jiangsu Co-Innovation Center of Efficient Processing and Utilization of Forest Resources, International \\ Innovation Center for Forest Chemicals and Materials, College of Chemical Engineering, Nanjing Forestry \\ University, Nanjing 210037, China; hanj1@njfu.edu.cn \\ 2 Institute of Chemistry, Jan Kochanowski University in Kielce, Uniwersytecka 7, 25-406 Kielce, Poland; \\ alicja.wzorek@ujk.edu.pl \\ 3 Molecular Structure Analysis, German Cancer Research Center (DKFZ), Im Neuenheimer Feld 280, \\ D-69120 Heidelberg, Germany \\ 4 Department of Organic Chemistry I, Faculty of Chemistry, University of the Basque Country UPV/EHU, \\ Paseo Manuel Lardizábal 3, 20018 San Sebastián, Spain \\ 5 IKERBASQUE, Basque Foundation for Science, Alameda Urquijo 36-5, Plaza Bizkaia, 48011 Bilbao, Spain \\ * Correspondence: k.klika@dkfz-heidelberg.de (K.D.K.); vadym.soloshonok@ehu.es (V.A.S.)
}

Citation: Han, J.; Wzorek, A.; Klika, K.D.; Soloshonok, V.A. Recommended Tests for the Self-Disproportionation of Enantiomers (SDE) to Ensure Accurate Reporting of the Stereochemical Outcome of Enantioselective Reactions. Molecules 2021, 26, 2757. https://doi.org/ $10.3390 /$ molecules 26092757

Academic Editor: Míriam Pérez Trujillo

Received: 25 April 2021

Accepted: 4 May 2021

Published: 7 May 2021

Publisher's Note: MDPI stays neutral with regard to jurisdictional claims in published maps and institutional affiliations.

Copyright: (c) 2021 by the authors. Licensee MDPI, Basel, Switzerland. This article is an open access article distributed under the terms and conditions of the Creative Commons Attribution (CC BY) license (https:/ / creativecommons.org/licenses/by/ $4.0 /)$.

\begin{abstract}
The purpose of this review is to highlight the necessity of conducting tests to gauge the magnitude of the self-disproportionation of enantiomers (SDE) phenomenon to ensure the veracity of reported enantiomeric excess (ee) values for scalemic samples obtained from enantioselective reactions, natural products isolation, etc. The SDE always occurs to some degree whenever any scalemic sample is subjected to physicochemical processes concomitant with the fractionation of the sample, thus leading to erroneous reporting of the true ee of the sample if due care is not taken to either preclude the effects of the SDE by measurement of the ee prior to the application of physicochemical processes, suppressing the SDE, or evaluating all obtained fractions of the sample. Or even avoiding fractionation altogether if possible. There is a clear necessity to conduct tests to assess the magnitude of the SDE for the processes applied to samples and the updated and improved recommendations described herein cover chromatography and processes involving gas-phase transformations such as evaporation or sublimation.
\end{abstract}

Keywords: self-disproportionation of enantiomers (SDE); enantiomeric analysis; molecular association; molecular chirality; enantiomeric excess

\section{Introduction}

As an integral part of our modern, innovation-driven industrialized society, the science of chemistry is undergoing dramatic changes, influencing the ways we learn, teach, conceptualize, and perform. One of the most noticeable signs of progress in the sciences is the exponential growth in the number of publications and their length, leading to everincreasing pagination of established journals and the appearance of numerous new ones. It can be posited that this uncontrolled growth is inevitably accompanied by a decrease in the quality of experimental results. A major groundbreaking solution to the problem of questionable results was the implementation of supporting material documenting the analytical data and compound characterizations conducted in the study, a means not previously feasible for any given reader prior to the invention of the Internet. Nevertheless, the quality and integrity of the experimental data are still major concerns [1-4]. Over the last decade, systematic research into the phenomenon of the self-disproportionation of enantiomers (SDE) [5-10] has clearly revealed that the accuracy in reporting the stereochemical outcome of enantioselective reactions represents a major issue of concern in terms 
of data integrity and the understanding of the stereochemical mechanisms at play and the interpretation of the results. It has been unequivocally shown that any physicochemical treatment, including achiral chromatography [10-43] or even rotary evaporation [40,44], of a scalemic sample inevitably leads to fractionation of the material into portions of variable enantiomeric excess (ee), with consequent erroneous reporting of the stereochemical outcome if due care is not taken. Yet, there is a deficiency in the general understanding and appreciation of the SDE phenomenon, even though it has been known for a considerable length of time now. While the SDE is unavoidable, its effect on the accuracy of the data reporting can be mitigated by simple SDE tests, which may reveal the SDE magnitude as a function of the physicochemical conditions, as well as the range of possible error for the data under the given conditions. We believe that overall knowledge of the nature and manifestation of the SDE phenomenon has come of age and the time is right for the introduction of mandatory SDE tests to be part of the supporting documentation and a cultured practice of research chemistry, as it is clearly necessary [45-47]. In this article, we provide a short overview of the SDE phenomenon, cite key examples of extraordinary cases, and suggest simple generic SDE tests via achiral chromatography and sublimation, to be performed as an integral part of the experimental work submitted for publication when the work concerns scalemic samples that arise from enantioselective reactions or as a result of natural products isolation. The updated and improved recommendations for tests described in this work cover chromatography and processes involving gas-phase transformations such as evaporation or sublimation. While warnings and recommendations have also been issued in the past, clear protocols for conducting SDE tests have not been prominently featured or detailed.

\section{Preview of the SDE}

\subsection{Origin and Purpose}

As some readers may not yet be familiar with the SDE phenomenon, we briefly summarize here some of the most important principles of the SDE. The term SDE was rationally designed [29], and its linguistic etymology, as well as the pros and cons of its application, have been discussed [48]. While the SDE is a relatively new term, it actually describes rather "old", quite well-known phenomena. For example, since 1895, or perhaps even earlier $[49,50]$, chemistry practitioners knew that the crystallization of partially resolved samples of chiral compounds (also variously described as optically active, nonracemic, enantiomerically enriched, or scalemic) usually resulted in a precipitate of greater, and concomitantly, a mother liquor of lower, ee in comparison with the starting material, i.e., there was a re-distribution (disproportionation) of the enantiomers among the fractions. By analogy with chemical purification by crystallization, this process is most commonly called "optical purification", or by a variety of other names involving optical/enantiomeric/chiral in combination with purification/enrichment/amplification [51-53]. Arguably, any combination of these aforementioned words does not describe correctly the outcome of a process producing simultaneously enantioenriched and -depleted fractions with no loss or gain in overall chirality. Accordingly, the introduction of appropriate terminology facilitating a chemically precise description of this type of physicochemical process was well overdue by the time that the SDE term was coined, though not only for reasons of scientific precision and methodological clarity. Due to the monotonously increasing accuracy of analytical methods, it became ever more apparent that processes resulting in the simultaneous formation of enantioenriched and -depleted fractions were not just limited to crystallization and, in fact, are rather ubiquitous with the SDE manifesting itself via virtually any type of physicochemical transformation.

\subsection{Areas of SDE Manifestation}

The areas of SDE manifestation can be divided into three major classes: physicochemical phase transitions, force field applications, and chromatography. We now briefly describe each of these in turn. 


\subsubsection{Physicochemical Phase Transitions}

Sublimation, a solid-to-gas phase transition, is, like crystallization, which will not be discussed since it is so well known, a classic method for the purification of crystalline organic compounds. However, SDE via sublimation (SDEvS)/evaporation (SDEvE) represents a major concern in regard to the accuracy of the experimental data, as the drying of reaction products under vacuum is usually an integral part of routine, reaction work-up procedures. Numerous examples of SDEvS have been reported [54-58] in the literature, strongly pointing to the necessity to control the ee integrity of samples by using an appropriate SDEvS test. Intriguingly, SDEvE, a liquid-to-gas phase transition, has even been observed by distillation [59-62], though convincing examples are extremely rare [63,64]. Among other potential SDE manifestations via phase transitions, liquid-to-liquid phase transition, as in extraction, can also be considered a possibility, and it is a process which plays a pivotal role in asymmetric catalysis using aqueous-organic bilayer conditions [65].

Sublimation, however, greatly differs in practice from recrystallization, as it is generally inconvenient to conduct it under equilibrium conditions for preparative purposes, as the gas phase is limited in how much mass it can contain, thus the occurrence of the SDE during sublimation primarily results from the different rates of transition from the solid state to the gaseous state of the racemic and enantiopure crystals, which is correlated to their thermodynamic stability. Particularly important for the kinetics of the sublimation process in practice are the manner in which the sample was prepared-mixed enantiopure crystals or mixed enantiopure and racemic crystals, crystal size and shape or amorphous, and origin of the samples if mixed. Confusion in the literature has resulted when attention has not been paid to this aspect [65]. It can be expected that the majority of compounds have euamotic points [57], i.e., they behave as racemic compounds by sublimation, just as the majority of compounds behave as racemic compounds by way of recrystallization. (Though it is interesting to note that sublimed material can adopt the alternate behavior $[42,53,66,67]$.) Moreover, as long as there are no strong kinetic effects and the system is under quasithermodynamically controlled conditions, the correct state of crystals are used (i.e., the sample is deposited from a solvent or the same solvent is used if a mixture of racemic and enantiopure samples is prepared), the same crystal dimensions are present by grinding the sample to a powder, there are no seeding effects, adiabatic passage applies, and there is no changeover from racemic compound behavior to conglomerate behavior, then the following empiricisms, which are a re-wording of Jacques et al. [51], apply:

1. There is very likely to be a euamotic point, since the vast majority of compounds are likely to be racemic compounds by sublimation in concert with their crystallization behavior,

2. Below the euamotic point, the more volatile portion enriches the sublimate and conversely above it, and

3. The portion with the lower melting point $(\mathrm{mp})$ is generally the more volatile (i.e., there is a correlation between $\mathrm{mp}$ and volatility) and which is typically the enantiomer.

Compounds that behave as conglomerates by sublimation, on the other hand, yield sublimates that are racemic.

\subsubsection{Force Field Applications}

Unlike recrystallization and sublimation, SDE via force field (SDEvFF) deals with the static case where molecules remain in their original starting crystal structures and a force field enacts separation due to differing crystal densities. According to Wallach's rule [49,50], for racemic compounds-representing more than $90 \%$ of crystalline organic compoundsthe racemic crystals are packed comparatively more tightly than the enantiopure crystals, thus resulting in higher densities for the former. A quite remarkable example of separating a mixture of racemic crystals and enantiopure crystals due to their different densities was realized [68] for a mechanical mixture of racemic and enantiopure crystals of (S)-alanine by density gradient ultracentrifugation. Another demonstration of SDEvFF was reported [69] for a simple dispersion of chiral compounds suspended in specially prepared liquids, maxi- 
mizing the difference in the densities of the racemic and enantiopure crystals. For example, in a mixture of chlorobenzene and bromobenzene as the suspension medium, the denser racemic crystals gravitated to the lower reaches of the system, while the lighter enantiopure crystals moved towards the upper reaches, allowing almost complete separation of the racemic portion from the enantiopure portion in the case of phenylalanine. Another very impressive example reported [70] using magnetic levitation to affect the SDE of ibuprofen, notable not just for the technique, but also for the fact that the enantiopure and racemic crystals of ibuprofen differ in density by only $\sim 2 \%$. Clearly, the cost effectiveness and outright operational convenience of these separations should be highly motivating for the development of practical large-scale enantiopurification procedures, especially in an industrial setting. Considering the overwhelming generality of the differences in crystal densities between racemic and enantiopure crystals, it is rather surprising that only a very limited number of reports on SDEvFF exist. One of the reasons might be because these reports seem to be almost completely unknown to the wider scientific community. We hope that the readers of this article will contribute to the due recognition and appreciation of this area of highly innovative research and its potential for unconventional means of enantiopurification [5,71]. In fact, the SDE has even found applications in conventional diastereomeric salt crystallization for the purposes of enantiopurification [72].

\subsubsection{Chromatography}

SDE via chromatography $(\mathrm{SDEvC})$ is arguably the major and the largest area of the SDE manifestation. The previous areas are all limited by crystallinity, volatility, and/or crystal density variance, properties possessed by less than $\sim 10 \%$ of chiral organic compounds. In sharp contrast, on the other hand, practically all compounds can be subjected to chromatography, as the conditions that can be applied are virtually limitless. Therefore, whether compounds are crystalline or liquid, of low or high molecular weight, polar or non-polar, etc., they are likely to be amenable to chromatography. Notably, SDEvC has been observed for all manner of chromatographic techniques, such as high-pressure liquid chromatography (HPLC) [11-17], medium-pressure liquid chromatography (MPLC) [18-21], routine, gravity-driven column chromatography [22-37], flash chromatography [35,38-40], preparative thin-layer chromatography (PTLC) $[10,41]$, and size-exclusion chromatography $[42,43]$, as well as under a variety of conditions such as normal- and reverse-phase conditions and for various stationary phases $[37,38]$. Some noteworthy theoretical studies [15,73-77] have been conducted on SDEvC to describe the process. Interestingly, there is a clear correlation between the rising sophistication and availability of chromatographic instrumentation and the increasing reporting of SDEvC cases in the literature [78]. The sheer number of examples reported thus far, as well as the structural variety of compounds for which the SDE is highly expressed, overwhelmingly support the necessity for SDEvC tests to be a mandatory part of modern experimental procedures.

\subsection{SDE-Phoric Groups}

It is worth emphasizing again that the SDE is a ubiquitous phenomenon that is always occurring anytime an enantioenriched sample is subjected to any type of physicochemical treatment, or simply being exposed to conditions conducive to physicochemical transformations, such as sublimation during storage $[10,66,79,80]$. There are several parameters to describe or quantify the SDE, e.g., SDE range, SDE yield, maximum theoretical SDE yield, etc. [5,48], but by far the most important is the SDE magnitude ( $\Delta$ ee), defined as [30]:

$$
\Delta \mathrm{ee}=\mathrm{ee}_{\text {fraction with the highest ee }}-\mathrm{ee}_{\text {fraction with the lowest ee }} \text {. }
$$

It should be noted that $\Delta$ ee can closely approach, but can never be equal to, $100 \%$. Conversely, while the SDE magnitude can be below the level of detection, it is never equal to zero. Additionally, it is important to note that the $\Delta$ ee is not only a function of a particular compound's structure but, to a great degree, also the conditions of the SDE experiment, such as the temperature, solvent/eluent used, impurities present, etc. Nevertheless, there 
is a significant degree of predictability of high SDE magnitude based purely on chemical structural features. From numerous literature data, it was deduced that molecules containing particular functional groups often have a propensity for exhibiting exceptionally high SDE magnitude, and such functional groups have been denoted as SDE-phoric groups [81]. Typically, the functional groups are strongly polarized and thus capable of forming strong intermolecular hydrogen $[22,26,31,34,40,81]$ or halogen bonds [82,83], or undergoing intermolecular dipole-dipole interactions $[11,38,84,85]$. For example, the $-\mathrm{CF}_{3}$-containing groups in $\mathbf{1}$ (Figure 1) and the C-F-containing groups in 2, unsurprisingly, due to their high electron withdrawing capability, can induce dipole-dipole interactions, as well as strongly enhancing the hydrogen bonding capability of other functional groups, such as $\mathrm{OH}[29,39,86]$ and $\mathrm{NH}[29,33]$. Indeed, substances containing fluorine [86,87] are known to often express exceptionally high SDE magnitudes by chromatography [34], sublimation [88,89], and even distillation [59-64]. This aspect is particularly important considering the rapid growth in the number of chiral, fluorine-containing pharmaceuticals [90-96] and agrochemicals [97-100]. Sulfoxides 3, due to the highly polarized S-O bond, are another example of an SDE-phoric group [26,71,85,101,102]. Of note, prazoles, S-O containing proton pump inhibitors that reduce the amount of acid produced in the stomach, are in the top 50 most prescribed drugs currently on the pharmaceutical market. Interestingly, both pantoprazole and lansoprazole [103] each contain both S-O and C-F groups.<smiles></smiles>

1<smiles></smiles>

2<smiles>[R][Sb]([R])([O-])[O-]</smiles>

3<smiles>[R]C(=O)N([2H])C([R])=O</smiles>

4<smiles>Oc1ccc2c(c1-c1c(O)ccc3c1CCCC3)CCCC2</smiles>

5

$$
\begin{aligned}
& \mathrm{R}^{1}=\text { Alk, } \mathrm{Ar}, \\
& -\mathrm{CO}_{2} \mathrm{R},-\mathrm{CH}_{2} \mathrm{CO}_{2} \mathrm{R}
\end{aligned}
$$

Figure 1. Examples of compounds 1-5 that contain SDE-phoric groups. The chiral center is marked with an asterisk in 1-4, while axial chirality is present in $\mathbf{5}$.

Of particular note are the $\mathrm{N}$-acyl amine-containing groups in $\mathbf{4}$ with an adjacent chiral center $[19,20,22,30,81,104]$, a ubiquitous structural feature of numerous natural compounds and pharmaceutical drugs. When $\mathrm{R}^{1}=-\mathrm{CO}_{2} \mathrm{R}$ or $-\mathrm{CH}_{2} \mathrm{CO}_{2} \mathrm{R}$, the structures include $\alpha$ - $[36,105,106]$ and $\beta$-amino [31,32] acid derivatives, respectively, such as peptides and peptidomimetics. There is no need to emphasize the exceptional hydrogen bonding properties of the $\mathrm{N}$-acyl amine group in 4 and the obvious importance of this class of compounds in modern organic synthesis, medicinal chemistry, and drug design [107-111]. Finally, the 1,1'-bi-2-phenol structural unit present in 5 exhibits extraordinary hydrogen bonding properties and is responsible for the very high SDE magnitude often observed for these compounds $[12,13,15,76,77,112-116]$. For example, BINOL, possessing this structural feature, is an exceptional asymmetric catalyst [117] and known for large nonlinear effects [118-121] as a consequence of its outstanding SDE properties.

\section{Pedagogic Examples from the Literature}

The SDE literature has been well reviewed previously, including generally [5,47], for particular processes, e.g., sublimation [54] and chromatography [45,46,78,122], as well as for specific SDE-phoric groups, e.g., sulfoxides [71,102], fluorine-containing compounds [86,87,123-125], amides [102,126], and amino acids and their derivatives [105]. Of note, SDEvS has been much less reported, for the obvious reason that it is simply a less utilized technique compared to chromatography for routine purification. In this section, we draw attention to some notable examples of serendipitous SDEvS/E and SDEvC discoveries made during the 
course of regular research work to highlight various aspects of the SDE. We also speculate on how the SDE could impact reported results if researchers are ignorant of the SDE or simply lack scientific curiosity if they happen to encounter the SDE.

\subsection{SDEvS}

As already pointed out, sublimation is a classical purification technique for organic compounds that has been routinely applied since the dawn of organic chemistry. Accordingly, it can be safely assumed that the purification of scalemates by sublimation has been performed countless times, especially, for example, during the isolation and purification of natural products. Surprisingly, therefore, it was not until 1959 when Dr. Gisela Pracejus [127] became the first pedant and thorough investigator curious enough to check the enantiopurity of both sublimed and residual portions after reaction products were subjected to routine purification by sublimation during a study of alkaloid-catalyzed addition reactions of alcohols to ketene $\mathbf{6}$ (Scheme 1). It was found that while the residue was chemically pure, it was a completely racemic product (rac)-7. In sharp contrast, the sublimed material 7 was enantioenriched to $\sim 10 \%$ ee, indicating a substantial difference in the sublimation rates between $(\mathrm{rac})-7$ and $(R)-7$. Obviously, if careful analysis of both sublime and residual material had not been conducted, the result of this work would be erroneously reported as disappointing, exhibiting no enantioselectivity and completely lacking as a promising opening approach for the catalytic asymmetric synthesis of amino acids.<smiles>O=C=C(Cc1ccccc1)N1C(=O)c2ccccc2C1=O</smiles>
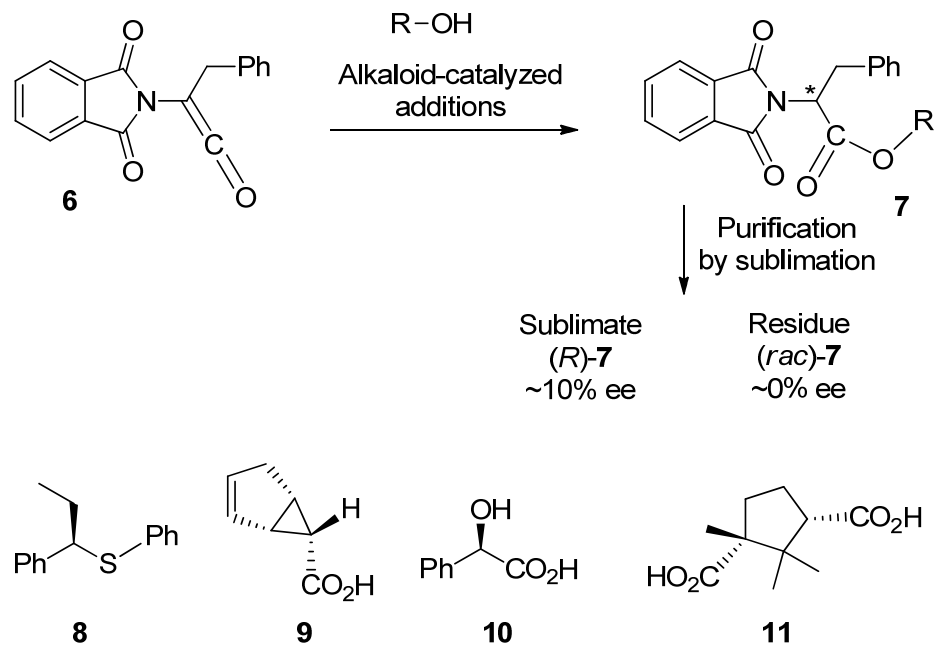<smiles>O=C(O)C(O)c1ccccc1</smiles><smiles>CC1[C@H](C(=O)O)CC[C@]1(C)O</smiles>

Scheme 1. Examples of compounds 6-11 that exhibit SDEvS. The chiral center is marked with an asterisk in 7 .

Surprisingly, this extraordinary discovery did not register in the research conscience of practitioners and SDEvS was only "discovered" again in 1967 [128] for compound 8, and then again a decade later in 1977 [129], for a series of naturally occurring compounds 9-11. Even the publication of these results in the American Chemical Society's Journal of Organic Chemistry in English was neither convincing nor helpful, as no one paid due attention to the accuracy of their experimental results, as further, new examples were not forthcoming until 1999 [44].

The most concerning case of unintentional SDEvE was encountered by Prof. John M. Brown [44] during work on the enantioselective hydroboration-oxidation of alkenes (Scheme 2). For the transformation of indene (12) to (R)-2,3-dihydro- $1 H$-inden-1-ol (13), the authors found disturbingly low reproducibility with regard to the enantiopurity of product 13. Meticulous examination of the experimental details revealed that the chemical yield and stereochemical outcome depended on length of exposure of product 13 to vacuum, in particular, removal by rotary evaporation of the reaction solvent. Aromatic alcohol $\mathbf{1 3}$ is particularly volatile, and the racemic portion of $\mathbf{1 3}$ can readily sublime, reducing the 
observed chemical yield and increasing the enantiopurity of the remainder. The fact that a routine work-up procedure such as evaporation of the reaction solvent resulted in significant alteration of the observed stereochemical outcome should be no less than alarming, and even disturbing, as it points to a very high probability that this kind of problem may have occurred frequently in the past. Nevertheless, this incident was not fully investigated and the paper has practically not been cited by other practitioners reporting on the enantioselective synthesis of volatile aromatic alcohols.

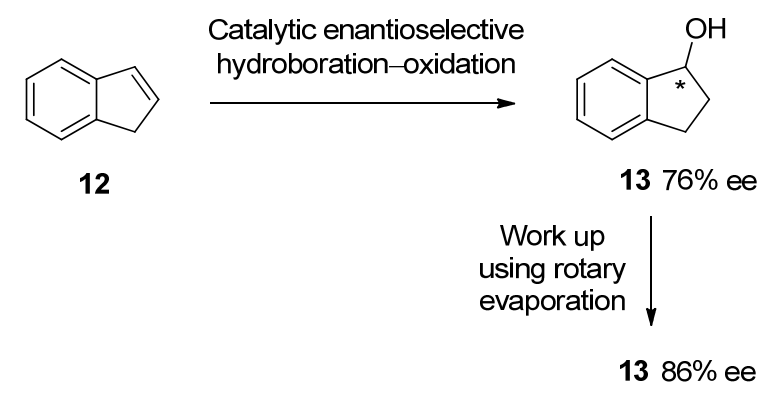

Scheme 2. An example of a compound that exhibited SDEvE under routine rotary evaporation in the work-up following reaction. The chiral center is marked with an asterisk in the product $\mathbf{1 3 .}$

Another noteworthy example is the fluorinated analog of lactic acid $\mathbf{1 4}$ (Scheme 3). Due to the exceptionally high volatility of compound 14 , sublimation readily takes place at ambient temperature and pressure. In a typical experiment, $300 \mathrm{mg}$ of acid 14 of $80 \%$ ee was spread over a Petri dish and left on a bench. After some 56 h, $80 \mathrm{mg}$ of enantiopure 14 was left behind in the Petri dish! Measurement of the sublimation rates revealed $[130,131]$ that racemic crystals of $\mathbf{1 4}$ sublimed about twice as fast in comparison to enantiopure crystals.<smiles>CC(O)(C(=O)O)C(F)(F)F</smiles>

$300 \mathrm{mg}, 80 \%$ ee<smiles>CC(C)OC(=O)C(O)C(F)(F)F</smiles>

15

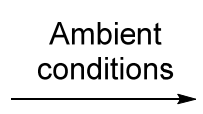<smiles>[R]NC(=O)C(O)C(F)(F)F</smiles>

16<smiles>CC(O)(C(=O)O)C(F)(F)F</smiles>

$80 \mathrm{mg},>99 \%$ ee<smiles>[R]NC(=O)C(C)(O)F</smiles>

17

Scheme 3. Examples of fluorinated analogs of lactic acid 14-17 that exhibit SDEvS. The chiral center is marked with an asterisk in 14-17.

Similar sublimation behaviors were reported for other types of fluorinated lactic acid derivatives, e.g., ester $\mathbf{1 5}$ [42,55] and amides $\mathbf{1 6}$ [88] and $\mathbf{1 7}$ [89]. In general, the introduction of fluorine into an organic compound, in particular, a trifluoromethyl or perfluoroalkyl group, noticeably increases the volatility of the resulting derivative. Considering the ever-increasing research into the design and synthesis of biologically active fluorinated compounds $[90-100,132,133]$, this property of fluorine-containing molecules should be taken very seriously. Thus, since many small organic compounds, especially fluorinecontaining ones, possess sufficiently high volatilities, they are prone to the SDE during processes involving gas-phase transformations. Even during the course of solvent removal under vacuum $[40,44]$ or sample drying, as well as the way in which the compounds are stored $[10,66,79,80]$, the ee of scalemic samples can be altered. Obviously then, SDEvS/E represents a major concern with regard to the quality and reliability of reported stereochemical outcomes of catalytic enantioselective reactions, as well as for the isolation of 
natural products and the handling of pharmaceutically active intermediates [123-125]. Taking into account that rotary evaporation and drying under vacuum are an innate part of routine reaction work-up and analytical sample preparation procedures, it is impossible to proffer arguments against the necessity to conduct a simple SDEvS test to ensure the accuracy of one's results. Hence, SDE tests for evaporation/sublimation should be considered obligatory.

\subsection{SDEvC}

As already mentioned, the SDEvC is the largest area of SDE manifestation. Presently, practically all newly reported compounds are obtained analytically pure by chromatography. Thus, whether compounds are crystalline or liquid, of low or high molecular weight, non-polar or polar, etc., they are likely to be subjected to chromatography. The first instances of SDEvC were independently discovered by Cundy and Crooks [134] in 1983, and a year later in 1984 by Charles and Gil-Av [25], their discoveries coinciding with the beginning of wide availability of HPLC instrumentation and improved sensitivity of analyte detection. Details of these pioneering papers can be found in the following review articles $[5,6,78,126]$. For the purposes of the present account, we discuss a few examples dealing with routine, gravity-driven column chromatography, since it is routinely used in virtually all research laboratories for the isolation and purification of reaction products.

One of the first and most remarkable examples was reported by Prof. Andre S. Dreiding [11] during the examination of the proline-catalyzed aldol cyclization of triketone $\mathbf{1 8}$ to bicyclic product 19 (Scheme 4). Having encountered a problem of low reproducibility of the stereochemical outcome and traced its origin to the chromatographic purification step, the authors performed a detailed investigation of the chromatographic behavior of enantioenriched diketone 19. In a key experiment, they subjected $200 \mathrm{mg}$ of 19 of $65 \%$ ee to achiral chromatography over silica gel using $n$-hexane-ethyl acetate (4:1) as an eluent, for which the ee and mass of each of the ten fractions they collected are given in Scheme 4. The authors concluded that achiral chromatography cannot be safely used for the purification of scalemates since, at least for this example, the outcome could be reported as high as $84 \%$ ee (the first fraction), as low as $51 \%$ ee (the last fraction), or anywhere in between. Pointedly, this report appeared well ahead of the "golden age" of organo-catalysis, where the chromatography of reaction mixtures to separate the products from the organo-catalyst is a typical part of the reaction work up. However, Dreiding's warning seemingly did not have much impact on research practice, remaining practically uncited. As an exception, we are pleased to note the recent work by Prof. Eusebio Juaristi [135], which serves as an example of how high-quality organo-catalytic research should be performed and reported. For other examples of high-quality experimental work on organo-catalytic and transition metal-catalyzed reactions, other recent papers [136,137] also stand out.

Chiral sulfoxides are in extremely high demand in academic research and the chemical industry concerned with the design and development of new synthetic reagents [138-141], drugs [142,143], and functional materials [144-148]. Due to the highly polar nature of the $\mathrm{S}-\mathrm{O}$ bond, scalemic sulfoxides are prone to the $\mathrm{SDEvC}$, rendering the sulfoxide functionality an SDE-phoric group [81]. This property is known to lead to mistakes in the evaluation of the sulfoxide enantiopurity if due care is not taken in the work up and purification steps $[80,85]$. The first warning of apparent difficulties caused by the SDEvC of enantioenriched sulfoxides was reported by Prof. Henri B. Kagan [38] in 1994. They demonstrated that the application of routine, achiral flash chromatography for the isolation or purification of sulfoxides can result in an erroneous description of the stereochemical outcome. For example, routine chromatography of a simple methyl $p$-tolyl sulfoxide $\mathbf{2 0}$ (Scheme 5) of $86 \%$ ee gave fractions of $\mathbf{2 0}$, with the ee ranging from $99.5 \%$ (first) to $73 \%$ (last). The alarming SDEvC properties of chiral sulfoxides were further conveyed by Kagan et al. in a series of successive publications [119,120,149-152], but the warning failed to influence the conservative mindset of the wider research community. Thus, out of some $700+$ papers reporting catalytic enantioselective synthesis of chiral sulfoxides that have been published 
since the seminal work, only one review [153] and four research reports [154-157] cite Kagan's work. One might speculate on how many reports on the catalytic asymmetric synthesis of sulfoxides may contain questionable, to say the least, data.<smiles>CC(=O)CCC1(C)C(=O)CCCC1=O</smiles>

18
$(S)$ or $(R)$-proline<smiles>CC12CCC(=O)C=C1CCCC2=O</smiles>

19

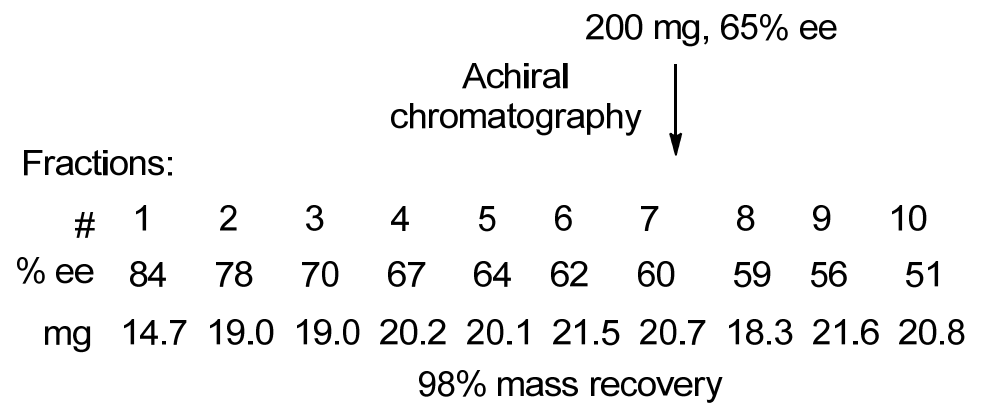

Scheme 4 . The SDEvC of product 19 by routine, gravity-driven column chromatography over silica gel using $n$-hexane-ethyl acetate (4:1) as eluent. The chiral center is marked with an asterisk in $\mathbf{1 9 .}$<smiles></smiles>

20<smiles>CCCCC[Sb](C)([O-])[O-]</smiles>

Flash chromatography First fraction $99.5 \%$ ee Last fraction $73.0 \%$ ee
Column chromatography First fraction $>99.9 \%$ ee

\section{1} Last fraction $7.8 \%$ ee

Scheme 5. The SDEvC of compounds 20 and 21 by flash and routine, gravity-driven column chromatography, respectively. The chiral center is marked with an asterisk in $\mathbf{2 0}$ and $\mathbf{2 1 .}$

Inspired by Kagan's work, several investigations $[26,71,80,85,102]$ revealed the remarkable persistence and high magnitude of the SDEvC for structurally varied chiral sulfoxides. In particular, SDE via routine, gravity-driven achiral column chromatography of methyl n-pentyl sulfoxide (21, Scheme 5) was systematically studied [85]. Parameters that were varied included the eluent, stationary phase, sample loading, temperature, and flow rate. The standout conclusion of the study was that while the SDE magnitude was strongly influenced by the nature of solvents used for elution, a noticeable value of the SDE was always observed regardless of the conditions, underscoring the strength of the intramolecular interactions leading to the persistence of the SDE. The influence of the eluent on the SDE magnitude can also be used to maximize $\Delta$ ee, allowing the development of an efficient enantiopurification method via simple column chromatography. As shown in Scheme 5, under SDE-optimized conditions, column chromatography allowed the fractionation of $\mathbf{2 1}$ relatively low $34.6 \%$ ee into fractions with ee's as high as $99.9 \%$ and as low as $7.8 \%$ [85]. Considering the pronounced SDEvC properties of chiral sulfoxides, one can confidently state that most of the reports on the enantioselective synthesis of this class of compounds could be due for a re-examination in terms of the reported stereospecific outcome [71] and possible re-evaluations of the results may be in order. 
Taking into account the ever-growing importance of fluorinated compounds in the design of modern pharmaceuticals [90-92,94-96] and agrochemicals [97-100], the trifluoromethylcontaining amino derivatives (Scheme 6) are given as the final example in this section. Thus, in the course of the development of biomimetic transamination [158], starting from either chiral imines 22 [159,160] and using a chiral based-catalyst [161,162], target amines 24 via 23 were transformed into amides 25 . However, it was found that the purification of amides 25 by routine, gravity-driven column chromatography resulted in low reproducibility of the stereochemical outcome of the reactions, prompting investigation of the underlying cause of the problem.

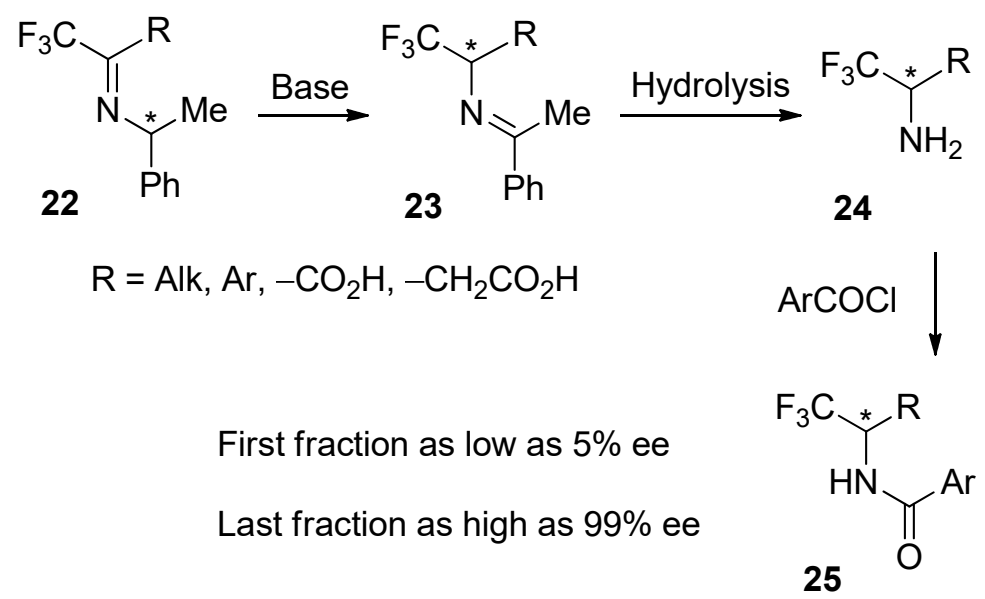

Scheme 6. The SDEvC of trifluoromethyl-containing amides 25 by routine, gravity-driven column chromatography over silica gel using $n$-hexane-ethyl acetate (5:1) as eluent. The chiral center is marked with an asterisk in 22-25.

It was found that, similar to sulfoxides, compounds 25 also exhibit high $\Delta$ ee's and a persistent SDE profile under a variety of chromatographic conditions. Following established methodology, the application of polar, protic solvents led to a decrease in $\Delta \mathrm{ee}$, while the use of aprotic, nonpolar solvents resulted in a noticeable increase in $\Delta \mathrm{ee}$. Under SDE-optimized conditions, routine, gravity-driven column chromatography provided enantiopure samples of amides 25, including $\alpha-\left(\mathrm{R}=-\mathrm{CO}_{2} \mathrm{H}\right)[163,164]$ and $\beta$-amino acids $\left(\mathrm{R}=-\mathrm{CH}_{2} \mathrm{CO}_{2} \mathrm{H}\right)[165,166]$, while the enantiodepleted fractions were as low as $5 \%$ ee $[29,33,86]$. It should be pointed out that amides 25 represent a combination of two SDE-phoric groups, $-\mathrm{CF}_{3}$ and $-\mathrm{CONH}-$, leading to strong homo- and heterochiral intermolecular interactions - the foundation of the SDE phenomenon. Considering literature data [87,123-125] and our own experience in the synthesis and properties of fluoro-organic compounds, in particular, catalytic enantioselective reactions [167-173], we can confidently conclude that practitioners working with $-\mathrm{CF}_{3}$-containing compounds should be ready to encounter noticeable magnitudes of the SDEvC (i.e., $\triangle$ ee $>5 \%$ ).

Similar to sublimation/evaporation, chromatography is also a key basic part of typical reaction work-up and the preparation of analytical samples. Notably, SDEvC has been reported for all manner of chromatographic techniques and stationary phases, including, as exemplified in this section, routine, gravity-driven column chromatography, as commonly used in any chemistry laboratory. Considering all these facts and data, it is inconceivable to come up with an argument against a mandatory requirement for performing SDEvC tests to ensure the accuracy, quality, and consistency of reported experimental results.

\section{Recommended SDEvS/E and SDEvC Tests}

\subsection{General Considerations}

The necessity of conducting tests to gauge the SDE magnitude to ensure the veracity of reported ee's cannot be overstated, since the SDE always occurs to some degree whenever a scalemic sample is subjected to physicochemical processes concomitant with fractionation 
of the sample, since even handling or storage can induce significant ee alterations to the bulk of a scalemic sample due to the SDE $[10,66,79,80]$. As we have documented, literature data confirm that whenever enantioenriched samples are handled, stored, or a physicochemical process applied, a test to gauge the magnitude of the SDE should be appropriately conducted, as ignorance of the SDE can lead to erroneous reporting of the ee of the sample if due care is not taken to either circumvent the SDE by measurement of the ee prior to the application of physicochemical processes, minimizing the SDE, or evaluating all obtained fractions of the sample (or avoiding fractionation altogether if possible). As outlined above, common physicochemical processes that are routinely performed in laboratories that can lead to the alteration of the ee due to the SDE, aside from obvious processes such as recrystallization and sublimation, include most, if not all, forms of achiral chromatography and even solvent evaporation under vacuum [40,44]. Indeed, the growing demand for accurate experimental data and increases in the sensitivity of analytical techniques has led to observations of the SDE in ever more processes; for example, SDE via PTLC has been reported [10,41] for the first time just recently. The important requirements for an SDE test are that it is an easy, fast, convenient, and simple procedure to perform. The main criterion for the tests is to match the conditions closely with those used in the work to evaluate the magnitude of the SDE under the applied conditions. Clearly, the major goal of proposing SDE tests via sublimation and chromatography is to ascertain the effect of the SDE and its magnitude on the compounds under study and to prevent the erroneous reporting of the stereochemical outcome. However, a secondary goal is to encourage the reporting of the SDE data collected under uniform conditions, allowing analysis, processing, and rationalization of the collected data. Additionally, we advocate the use of SDEvC for the routine preparation of enantiopure analytical samples, and thus foster a new research practice of obtaining chiral compounds as enantiopure, not simply having them as they are obtained from reactions lacking any enantioenrichment. Analogy can be seen with the chemical purity of compounds and how they evolved from as-obtainedfrom-the-reaction to a standard of chemical purity supported by analytical data. For the proposed SDE tests, we were careful to make the tests practical and simple to minimize resistance based on the required time, labor, and/or the cost of reagents. Having conducted the SDE test(s), this can be stated in the experimental section, along with the conclusions and the results of the SDE tests lodged in the supporting documentation.

\subsection{SDEvS Test}

The SDEvS test should be conducted for at least one representative compound of a series prepared and isolated by the same procedure. A compound bearing a substituent such as $-\mathrm{CF}_{3}$, tert-butyl, isopropyl, a long alkyl chain, or an aromatic group, if available, is best, as these groups generally impart increased volatility to organic compounds. It is suggested to use as much material as possible for the test, perhaps as much as $50 \mathrm{mg}$, to minimize weighing and other errors and, most importantly, to use analytically pure material, i.e., chemically pure and both solvent and water free, to avoid errors with the mass loss. Since the majority of the material is recovered from the test, the use of large quantities is feasible, and thus the choice of compound to be used for the test may also be determined by availability. The ee of the sample can be anywhere between 0 and $100 \%$ ee, though if available, a sample of $\sim 50 \%$ ee is recommended to allow for similar sublimations of the racemic and enantiomeric excess portions.

Step 1. Take $50 \mathrm{mg}$ of known exact mass and ee of the representative compound and leave in a flask for $12 \mathrm{~h}$ at $60^{\circ} \mathrm{C}$ and subjected to a pressure of $\sim 80 \mathrm{mbar}$. Afterwards, weigh the sample and in the case of scenario a, the mass is unchanged, in which case the test is completed and there are likely no complications with the SDEvS. For scenario $b$, the mass has decreased, in which case, measure the ee of the sample to confirm whether the mass loss has led to a decrease or increase in the ee and then proceed to Step 2.

Step 2. Conduct sublimation of the sample in a sublimation apparatus, collecting both the sublimed and residual material and measure their ee's. In addition, other samples of 
the compound of differing ee should also be examined, as the ee selected may happen to be close to the euamotic point, thus samples with ee's far from the ee of the first sample, either much higher or lower or even both, should be subjected to sublimation for a complete evaluation of the SDEvS. In this instance, it is also worth checking a sample with an ee close to the ee's of the samples produced in the work. Other compounds from the work should also be studied and alterations to the isolation and characterization procedures should be made and the reported data adjusted accordingly. Depending on the level of interest, crystallographic data can be collected to explain the observed rates of sublimations, and obviously, any additional work could potentially be published separately as a valuable contribution to SDE research.

Though the routine measurement of mp's seems to have fallen out of favor, it is still recommended [1], since for compounds which behave as racemic compounds by sublimation, similar mp's for enantiopure and racemic samples of a compound will likely only result in small $\triangle$ ee's by SDEvS [10]. While similar mp's may provide some comfort that the SDEvS might be small in the short term, unfortunately it will not ensure that the SDEvS will be insignificant for an extended period of time under vacuum or for long-term storage. For compounds which behave as conglomerates by sublimation, the sublimate is always racemic and thus the ee of the residue can be drastically altered rather quickly with the progress of sublimation.

\subsection{SDEvC Test}

The SDEvC test should be conducted for at least one representative compound of a series prepared and isolated by the same procedure. Taking into account that intermolecular interactions and the dynamic formation of the homo- and heterochiral species are the underlying mechanism for the $\mathrm{SDEvC}$, it is suggested to select a compound bearing a polar substituents such as $-\mathrm{CF}_{3},-\mathrm{NO}_{2},-\mathrm{OH},-\mathrm{NH}_{2}$, etc., amide, $-\mathrm{SO},-\mathrm{SO}_{2}$, acyl, or any other group that can facilitate hydrogen bonding or dipole-dipole interactions. It is suggested to use as much material as possible for the test, perhaps as much as $50 \mathrm{mg}$ in the case of routine, gravity-driven column chromatography, to minimize weighing (e.g., for small quantities in collected fractions) and other errors, and to use analytically pure material, i.e., chemically pure and both solvent and water free, to avoid errors with possible mass losses. Since the majority of the material is recovered from the test, the use of large quantities is feasible, and thus, the choice of compound to be used for the test may also be determined by availability. The ee of the sample can be anywhere between 0 and $100 \%$ ee, though it is also worth testing a sample with an ee close to the ee's of the samples produced in the work. However, if available, a sample of $\sim 60-70 \%$ ee is preferred, as we have found that this often provides the largest $\Delta \mathrm{ee}$ 's. The eluent, flow rate, and sample loading (relative to the amount of stationary phase) should be kept the same as in the general experimental procedure, to evaluate the effect of the SDEvC. The SDEvC is concentration dependent, so it is vitally important that lower concentrations are not used in the test compared with the general experimental procedure, and hence also why large amounts of material are recommended for the test.

Step 1. Take $50 \mathrm{mg}$ of known exact mass and ee of the representative compound and subject it to chromatography using the same purification procedure as applied in the work. The elution of the compound should be fractionated with the first fraction consisting of $\sim 5-10 \%$ of the weight, followed by three more-or-less equal fractions of $\sim 30 \%$, which may typically be $10 \mathrm{~mL}$ in volume for column chromatography, and then one final, very large fraction collected as the "tail", which is necessarily highly diluted due to the collection of a large volume. Afterwards, the ee of all five fractions should be determined, e.g., by chiral HPLC, and in the case of scenario a, the maximum $\triangle$ ee for the fractions is less than $5 \%$ ee, in which case, one can proceed accordingly under the assumption that the influence of the $\mathrm{SDEvC}$ on the recorded ee's is minimal or even insignificant and the values can be reported appropriately as $\pm 5 \%$ ee or by whatever $\Delta$ ee value has been determined. Alternatively, the eluent can be modified by increasing the portion of the polar ingredient to suppress 
the intermolecular interactions, and therefore the magnitude of the SDE. The SDEvC test should then be repeated with the new eluent composition to confirm the decrease in the $\Delta \mathrm{ee}$. If successful, the general experimental procedure should be adjusted using the modified eluent. Of note, this adjustment of the eluent can work for SDE magnitudes far greater than $5 \%$ ee, by using protic, polar solvents such as alcohols, which have very powerful suppressive effects on hydrogen bond-based and dipole-dipole intermolecular interactions and therefore manifestation of the SDEvC. For scenario b, if $\triangle$ ee exceeds $5 \%$ ee, one should follow the experiment described in the seminal publication by Prof. Andre S. Dreiding [11] This experiment should then be a special section in the ensuing paper, with a proper discussion on how the reported stereochemistry values were obtained, mitigating the impact of the SDEvC. Depending on the level of interest, one could follow the guidelines of paper [85] to investigate all aspects of the phenomenon, develop an SDEvC-optimized procedure, and then use the SDEvC for the preparation of enantiopure samples of the compounds under study. As stated above, a sample of $\sim 60-70 \%$ ee often provides the largest $\Delta \mathrm{ee}$ 's, especially when the polarity of the eluent is adjusted such that an $R_{\mathrm{f}}$ value of between $0.2-0.3$ is obtained and the amount of stationary phase that is used in column chromatography is set according to a ratio of $1 \mathrm{mmol}$ of compound/30 $\mathrm{g}$ stationary phase. Obviously, any additional work could potentially be published separately as a valuable contribution to SDE research.

\section{Conclusions and Afterword}

\subsection{Conclusions}

The importance and necessity of conducting tests to gauge the magnitude of the SDE phenomenon to ensure the veracity of reported ee's for scalemic samples obtained from, for example, enantioselective reaction or by the isolation of natural products, has been enunciated. It has to be recognized that the SDE is always occurring to some degree whenever any scalemic sample is subjected to a physicochemical process concomitant with fractionation of the sample and the question is how to minimize-ideally, eliminate to all intents and purposes-its potentially detrimental effect on the true value of the ee. Thus, erroneous reporting of the true ee of samples can occur if due care is not taken to either preclude the effects of the SDE by measurement of the ee prior to the application of physicochemical processes, suppressing the SDE, or evaluating all obtained fractions of the sample - or even avoiding fractionation altogether if possible-and in regard to measuring the ee [4]. Thus, there is a clear necessity to conduct tests to assess the magnitude of the SDE for the processes applied to samples. However, despite a clear call for conducting SDE tests in the past [174], only a few groups [80,135,167,171-173,175-181] have taken on the recommendation, but we hope that with the updated and improved recommendations described herein, which cover chromatography and processes involving gas-phase transformations such as evaporation or sublimation, that it will become standard practice for the conduct of high-quality research involving enan-tioselective reactions, natural products, and other work involving chiral compounds.

\subsection{Afterword}

A logical consequence of a wide acceptance of the SDE and legitimization of the SDE tests, of course, would be to put into question many, if not practically all, previously reported results on the stereochemical outcome of enantioselective reactions and the stereochemical state of isolated natural products. Considering the ubiquitous nature of the SDE phenomenon and its manifestation via such standard techniques of routine work-up procedures such as evaporation, drying, and achiral chromatography, such a view is obviously valid. Accepting that some stereochemical data from the past may actually be of greater or lower ee than reported does not, however, alter or depreciate the ingenuity, innovation, and synthetic value of the developed methods. As outlined in this article, the research data on the SDE phenomenon have reached a critical mass clearly indicating the necessity for introducing SDE tests. In fact, it is impossible to find any scientifically 
based argument against the proposal to improve the quality of reported data, credibility of research, and public perception of science as a self-correcting entity. Bearing in mind ever-increasing budgetary constraints, limited resources, and demands on research time, we have suggested a minimum of essential tests for only one extra experiment for one representative compound to estimate the potential magnitude of the SDEvS or SDEvC. In cases of high SDE magnitude, the additional research work is not a burden, but rather, a logical extension of the original research. Thus, while the scientific aspect of the SDE tests in terms of acceptance is beyond discussion, the political thinking of the editorial boards can be an issue, as authors may naturally tend to submit and publish following a course of least resistance. However, sooner or later, it is expected that SDE tests will become obligatory and considered as standard practice in research laboratories dealing with chiral compounds.

Author Contributions: Conceptualization, V.A.S.; methodology, A.W.; formal analysis, A.W.; data curation, J.H., A.W., K.D.K., V.A.S.; writing-original draft preparation, J.H., A.W., K.D.K., V.A.S.; writing-review and editing, J.H., A.W., K.D.K., V.A.S. All authors have read and agreed to the published version of the manuscript.

Funding: This research received no external funding.

Acknowledgments: V.A.S. gratefully acknowledges support from IKERBASQUE, the Basque Foundation for Science.

Conflicts of Interest: The authors declare no conflict of interest.

\section{References}

1. Wernerova, M.; Hudlicky, T. On the practical limits of determining isolated product yields and ratios of stereoisomers: Reflections, analysis, and redemption. Synlett 2010, 2010, 2701-2707.

2. Noyori, R.; Richmond, J.P. Ethical conduct in chemical research and publishing. Adv. Synth. Catal. 2013, 355, 3-8. [CrossRef]

3. Carlson, R.; Hudlicky, T. On hype, malpractice, and scientific misconduct in organic synthesis. Helv. Chim. Acta 2012, 95, 2052-2062. [CrossRef]

4. Payne, C.; Kass, S.R. How reliable are enantiomeric excess measurements obtained by chiral HPLC? ChemistrySelect 2020, 5, 1810-1817. [CrossRef]

5. Han, J.; Kitagawa, O.; Wzorek, A.; Klika, K.D.; Soloshonok, V.A. The self-disproportionation of enantiomers (SDE): A menace or an opportunity? Chem. Sci. 2018, 9, 1718-1739. [CrossRef] [PubMed]

6. Han, J.; Wzorek, A.; Soloshonok, V.A.; Klika, K.D. The self-disproportionation of enantiomers (SDE): The effect of scaling down, potential problems versus prospective applications, possible new occurrences, and unrealized opportunities? Electrophoresis 2019, 40, 1869-1880. [CrossRef]

7. Pietrusiewicz, K.M.; Borkowski, M.; Strzelecka, D.; Kielar, K.; Kicińska, W.; Karevych, S.; Jasiński, R.; Demchuk, O.M. A general phenomenon of spontaneous amplification of optical purity under achiral chromatographic conditions. Symmetry 2019, 11, 680. [CrossRef]

8. Tokunaga, E.; Yamamoto, T.; Ito, E.; Shibata, N. Understanding the thalidomide chirality in biological processes by the selfdisproportionation of enantiomers. Sci. Rep. 2018, 8, 17131. [CrossRef] [PubMed]

9. Dutta, S.; Gellman, A.J. Enantiomer surface chemistry: Conglomerate versus racemate formation on surfaces. Chem. Soc. Rev. 2017, 46, 7787-7839. [CrossRef] [PubMed]

10. Kwiatkowska, M.; Wzorek, A.; Kołbus, A.; Urbaniak, M.; Han, J.; Soloshonok, V.A.; Klika, K.D. Flurbiprofen: A study of the behavior of the scalemate by chromatography, sublimation, and NMR. Symmetry 2021, 13, 543. [CrossRef]

11. Tsai, W.-L.; Hermann, K.; Hug, E.; Rohde, B.; Dreiding, A.S. Enantiomer-differentiation induced by an enantiomeric excess during chromatography with achiral phases. Helv. Chim. Acta 1985, 68, 2238-2243. [CrossRef]

12. Dobashi, A.; Motoyama, Y.; Kinoshita, K.; Hara, S.; Fukasaku, N. Self-induced chiral recognition in the association of enantiomeric mixtures on silica gel chromatography. Anal. Chem. 1987, 59, 2209-2211. [CrossRef]

13. Matusch, R.; Coors, C. Chromatographic separation of the excess enantiomer under achiral conditions. Angew. Chem. Int. Ed. 1989, 28, 626-627. [CrossRef]

14. Loža, E.; Lola, D.; Kemme, A.; Freimanis, J. Enantiomeric enrichment of partially resolved 4-hydroxy-2-carboxymethylcyclopentanone derivatives by achiral phase chromatography. J. Chromatogr. A 1995, 708, 231-243. [CrossRef]

15. Nicoud, R.-M.; Jaubert, J.-N.; Rupprecht, I.; Kinkel, J. Enantiomeric enrichment of non-racemic mixtures of binaphthol with non-chiral packings. Chirality 1996, 8, 234-243. [CrossRef]

16. Monde, K.; Harada, N.; Takasugi, M.; Kutschy, P.; Suchy, M.; Dzurilla, M. Enantiomeric excess of a cruciferous phytoalexin, spirobrassinin, and its enantiomeric enrichment in an achiral HPLC system. J. Nat. Prod. 2000, 63, 1312-1314. [CrossRef] 
17. Suchý, M.; Kutschy, P.; Monde, K.; Goto, H.; Harada, N.; Takasugi, M.; Dzurilla, M.; Balentová, E. Synthesis, absolute configuration, and enantiomeric enrichment of a cruciferous oxindole phytoalexin, (S)-(-)-Spirobrassinin, and its oxazoline analog. J. Org. Chem. 2001, 66, 3940-3947. [CrossRef] [PubMed]

18. Tateishi, K.; Tsukagoshi, S.; Nakamura, T.; Watanabe, S.; Soloshonok, V.A.; Kitagawa, O. Chiral initiator-induces selfdisproportionation of enantiomers via achiral chromatography: Application to enantiomer separation of racemate. Tetrahedron Lett. 2013, 54, 5220-5223. [CrossRef]

19. Goto, M.; Tateishi, K.; Ebine, K.; Soloshonok, V.A.; Roussel, C.; Kitagawa, O. Chiral additive induced self-disproportionation of enantiomers under MPLC conditions: Preparation of enantiomerically pure samples of 1-(aryl)ethylamines from racemates. Tetrahedron Asymmetry 2016, 27, 317-321. [CrossRef]

20. Nakamura, T.; Tateishi, K.; Tsukagoshi, S.; Hashimoto, S.; Watanabe, S.; Soloshonok, V.A.; Aceña, J.L.; Kitagawa, O. Selfdisproportionation of enantiomers of non-racemic chiral amine derivatives through achiral chromatography. Tetrahedron 2012, 68, 4013-4017. [CrossRef]

21. Kosugi, H.; Abe, M.; Hatsuda, R.; Uda, H.; Kato, M. A study of asymmetric protonation with chiral $\beta$-hydroxy sulfoxides. Asymmetric synthesis of (-)-epibatidine. Chem. Commun. 1997, 1857-1858. [CrossRef]

22. Suzuki, Y.; Han, J.; Kitagawa, O.; Aceña, J.L.; Klika, K.D.; Soloshonok, V.A. A comprehensive examination of the selfdisproportionation of enantiomers (SDE) of chiral amides via achiral, laboratory-routine, gravity-driven column chromatography. RSC Adv. 2015, 5, 2988-2993. [CrossRef]

23. Tanaka, K.; Osuga, H.; Suzuki, H.; Shogase, Y.; Kitahara, Y. Synthesis, enzymic resolution and enantiomeric enhancement of bis(hydroxymethyl)[7]thiaheterohelicenes. J. Chem. Soc. Perkin Trans. 1 1998, 935-940. [CrossRef]

24. Ernholt, B.V.; Thomsen, I.B.; Lohse, A.; Plesner, I.W.; Jensen, K.B.; Hazell, R.G.; Liang, X.; Jacobsen, A.; Bols, M. Enantiospecific synthesis of 1-Azafagomine. Chem. Eur. J. 2000, 6, 278-287. [CrossRef]

25. Charles, R.; Gil-Av, E. Self-amplification of optical activity by chromatography on an achiral adsorbent. J. Chromatogr. 1984, 298, 516-520. [CrossRef]

26. Song, W.; Zhou, Y.; Fu, Y.; Xu, W. Self-disproportionation of enantiomers of prazoles via achiral, gravity-driven silica gel column chromatography. Tetrahedron Asymmetry 2013, 24, 909-912. [CrossRef]

27. Zheng, J.; You, S.-L. Construction of axial chirality by rhodium-catalyzed asymmetric dehydrogenative heck coupling of biaryl compounds with alkenes. Angew. Chem. Int. Ed. 2014, 53, 13244-13247. [CrossRef] [PubMed]

28. Maeno, M.; Kondo, H.; Tokunaga, E.; Shibata, N. Synthesis of fluorinated donepezil by palladium-catalyzed decarboxylative allylation of $\alpha$-fluoro- $\beta$-keto ester with tri-substituted heterocyclic alkene and the self-disproportionation of its enantiomers. RSC Adv. 2016, 6, 85058-85062. [CrossRef]

29. Soloshonok, V.A. Remarkable amplification of the self-disproportionation of enantiomers on achiral-phase chromatography columns. Angew. Chem. Int. Ed. 2006, 45, 766-769. [CrossRef] [PubMed]

30. Wzorek, A.; Sato, A.; Drabowicz, J.; Soloshonok, V.A.; Klika, K.D. Enantiomeric enrichments via the self-disproportionation of enantiomers (SDE) by achiral, gravity-driven column chromatography: A case study using $N$-(1-Phenylethyl)acetamide for optimizing the enantiomerically pure yield and magnitude of the SDE. Helv. Chim. Acta 2015, 98, 1147-1159. [CrossRef]

31. Wzorek, A.; Sato, A.; Drabowicz, J.; Soloshonok, V.A.; Klika, K.D. Remarkable magnitude of the self-disproportionation of enantiomers (SDE) via achiral chromatography; application to the practical-scale enantiopurification of $\beta$-amino acid esters. Amino Acids 2016, 48, 605-613. [CrossRef] [PubMed]

32. Kwiatkowska, M.; Marcinkowska, M.; Wzorek, A.; Pajkert, R.; Han, J.; Klika, K.D.; Soloshonok, V.A.; Röschenthaler, G.-V. The selfdisproportionation of enantiomers (SDE) via column chromatography of $\beta$-amino- $\alpha, \alpha$-difluorophosphonic acid derivatives. Amino Acids 2019, 51, 1377-1385. [CrossRef] [PubMed]

33. Soloshonok, V.A.; Berbasov, D.O. Self-Disproportionation of enantiomers of (R)-Ethyl 3-(3,5-Dinitrobenzamido)-4,4,4trifluorobutanoate on achiral silica gel stationary phase. J. Fluorine Chem. 2006, 127, 597-603. [CrossRef]

34. Maeno, M.; Tokunaga, E.; Yamamoto, T.; Suzuki, T.; Ogino, Y.; Ito, E.; Shiro, M.; Asahi, T.; Shibata, N. Self-disproportionation of enantiomers of thalidomide and its fluorinated analogue via gravity-driven achiral chromatography: Mechanistic rationale and implications. Chem. Sci. 2015, 6, 1043-1048. [CrossRef] [PubMed]

35. Ogawa, S.; Nishimine, T.; Tokunaga, E.; Nakamura, S.; Shibata, N. Self-disproportionation of enantiomers of heterocyclic compounds having a tertiary trifluoromethyl alcohol center on chromatography with a non-chiral system. J. Fluorine Chem. 2010, 131, 521-524. [CrossRef]

36. Hosaka, T.; Imai, T.; Wzorek, A.; Marcinkowska, M.; Kolbus, A.; Kitagawa, O.; Soloshonok, V.A.; Klika, K.D. The selfdisproportionation of enantiomers (SDE) of $\alpha$-amino acid derivatives; facets of steric and electronic properties. Amino Acids 2019, 51, 283-294. [CrossRef] [PubMed]

37. Mayani, V.J.; Abdi, S.H.R.; Kureshy, R.I.; Khan, N.H.; Agrawal, S.; Jasra, R.V. Enantiomer self-disproportionation of chiral compounds on achiral ordered mesoporous silica M41S and regular silica gel as a stationary phase. Chirality 2009, 21, 255-261. [CrossRef] [PubMed]

38. Diter, P.; Taudien, S.; Samuel, O.; Kagan, H.B. Enantiomeric enrichment of sulfoxides by preparative flash chromatography on an achiral phase. J. Org. Chem. 1994, 59, 370-378. [CrossRef] 
39. Sorochinsky, A.E.; Katagiri, T.; Ono, T.; Wzorek, A.; Aceña, J.L.; Soloshonok, V.A. Optical purifications via self-disproportionation of enantiomers by achiral chromatography: Case study of a series of $\alpha-\mathrm{CF}_{3}$-containing secondary alcohols. Chirality 2013, 25, 365-368. [CrossRef] [PubMed]

40. Abás, S.; Arróniz, C.; Molins, E.; Escolano, C. Access to the enantiopure pyrrolobenzodiazepine (PBD) dilactam nucleus via self-disproportionation of enantiomers. Tetrahedron 2018, 74, 867-871. [CrossRef]

41. Baumann, A.; Wzorek, A.; Soloshonok, V.A.; Klika, K.D.; Miller, A.K. Potentially mistaking enantiomers for different compounds due to the self-induced diastereomeric anisochronism (SIDA) phenomenon. Symmetry 2020, 12, 1106. [CrossRef]

42. Aceña, J.L.; Sorochinsky, A.E.; Katagiri, T.; Soloshonok, V.A. Unconventional preparation of racemic crystals of isopropyl 3,3,3-trifluoro-2-hydroxypropanoate and their unusual crystallographic structure: The ultimate preference for homochiral intermolecular interactions. Chem. Commun. 2013, 49, 373-375. [CrossRef]

43. Ishida, Y.; Aida, T. Homochiral supramolecular polymerization of an "S"-shaped chiral monomer: Translation of optical purity into molecular weight distribution. J. Am. Chem. Soc. 2002, 124, 14017-14019. [CrossRef] [PubMed]

44. Doucet, H.; Fernandez, E.; Layzell, T.P.; Brown, J.M. the scope of catalytic asymmetric hydroboration/oxidation with rhodium complexes of 1,1'-(2-Diarylphosphino-1-naphthyl)isoquinolines. Chem. Eur. J. 1999, 5, 1320-1330. [CrossRef]

45. Martens, J.; Bhushan, R. Purification of enantiomeric mixtures in enantioselective synthesis: Overlooked errors and scientific basis of separation in achiral environment. Helv. Chim. Acta 2014, 97, 161-187. [CrossRef]

46. Martens, J.; Bhushan, R. Enantioseparations in achiral environments and chromatographic systems. Isr. J. Chem. 2016, 56, 990-1009. [CrossRef]

47. Sorochinsky, A.E.; Soloshonok, V.A. Self-disproportionation of enantiomers of enantiomerically enriched compounds. In Differentiation of Enantiomers II; Schurig, V., Ed.; Springer: Cham, Switzerland, 2013; Volume 341, pp. 301-340.

48. Soloshonok, V.A.; Klika, K.D. Terminology related to the phenomenon 'self-disproportionation of enantiomers' (SDE). Helv. Chem. Acta 2014, 97, 1583-1589. [CrossRef]

49. Wallach, O. Zur kenntniss der terpene und der ätherischen oele. Ueber gebromte derivate der carvonreihe. Justus Liebigs Ann. Chem. 1895, 286, 119-143. [CrossRef]

50. Pratt Brock, C.; Schweizer, W.B.; Dunitz, J.D. On the validity of Wallach's rule: On the density and stability of racemic crystals compared with their chiral counterparts. J. Am. Chem. Soc. 1991, 113, 9811-9820. [CrossRef]

51. Jacques, J.; Collet, A.; Wilen, S.H. Enantiomers, Racemates, and Resolutions; Wiley \& Sons, Inc.: New York, NY, USA, 1981.

52. O'Donnell, M.J.; Delgado, F. Enantiomeric enrichment of $\alpha$-amino acid derivatives: Recrystallization of $N$-Fmoc $\alpha$-amino acid tert-butyl esters. Tetrahedron 2001, 57, 6641-6650. [CrossRef]

53. Cintas, P.; Viedma, C. On the physical basis of asymmetry and homochirality. Chirality 2012, 24, 894-908. [CrossRef]

54. Han, J.; Nelson, D.J.; Sorochinsky, A.E.; Soloshonok, V.A. Self-disproportionation of enantiomers via sublimation; new and truly green dimension in optical purification. Curr. Org. Synth. 2011, 8, 310-317. [CrossRef]

55. Yasumoto, M.; Ueki, H.; Ono, T.; Katagiri, T.; Soloshonok, V.A. Self-disproportionation of enantiomers of isopropyl 3,3,3(trifluoro)lactate via sublimation: Sublimation rates vs. enantiomeric composition. J. Fluorine Chem. 2010, 131, 535-539. [CrossRef]

56. Ueki, H.; Yasumoto, M.; Soloshonok, V.A. Rational application of self-disproportionation of enantiomers via sublimation-a novel methodological dimension for enantiomeric purifications. Tetrahedron Asymmetry 2010, 21, 1396-1400. [CrossRef]

57. Tarasevych, A.V.; Sorochinsky, A.E.; Kukhar, V.P.; Chollet, A.; Daniellou, R.; Guillemin, J.-C. Partial sublimation of enantioenriched amino acids at low temperature. Is it coming from the formation of a euatmotic composition of the gaseous phase? J. Org. Chem. 2013, 78, 10530-10533. [CrossRef] [PubMed]

58. Nanita, S.C.; Cooks, R.G. Serine octamers: Cluster formation, reactions, and implications for biomolecule homochirality. Angew. Chem. Int. Ed. 2006, 45, 554-569. [CrossRef]

59. Katagiri, T.; Takahashi, S.; Tsuboi, A.; Suzaki, M.; Uneyama, K. Discrimination of enantiomeric excess of optically active trifluorolactate by distillation: Evidence for a multi-center hydrogen bonding network in the liquid state. J. Fluorine Chem. 2010, 131, 517-520. [CrossRef]

60. Katagiri, T.; Uneyama, K. Chiral recognition by multicenter single proton hydrogen bonding of trifluorolactates. Chem. Lett. 2001, 30, 1330-1331. [CrossRef]

61. Katagiri, T.; Yoda, C.; Furuhashi, K.; Ueki, K.; Kubota, T. Separation of an enantiomorph and its racemate by distillation: Strong chiral recognizing ability of trifluorolactates. Chem. Lett. 1996, 25, 115-116. [CrossRef]

62. Koppenhoefer, B.; Trettin, U. Is it possible to affect the enantiomeric composition by a simple distillation process? Fresenius Z. Anal. Chem. 1989, 333, 750. [CrossRef]

63. Zehnacker, A.; Suhm, M.A. Chirality recognition between neutral molecules in the gas phase. Angew. Chem. Int. Ed. 2008, 47, 6970-6992. [CrossRef]

64. Albrecht, M.; Soloshonok, V.A.; Schrader, L.; Yasumoto, M.; Suhm, M.A. Chirality-dependent sublimation of $\alpha$-(trifluoromethyl)lactic acid: Relative vapor pressures of racemic, eutectic, and enantiomerically pure forms, and vibrational spectroscopy of isolated $(S, S)$ and $(S, R)$ dimers. J. Fluorine Chem. 2010, 131, 495-504. [CrossRef]

65. Blackmond, D.G.; Klussmann, M. Spoilt for choice: Assessing phase behavior models for the evolution of homochirality. Chem. Commun. 2007, 3990-3996. [CrossRef] [PubMed]

66. Soloshonok, V.A.; Ueki, H.; Yasumoto, M.; Mekala, S.; Hirschi, J.S.; Singleton, D.A. Phenomenon of optical self-purification of chiral non-racemic compounds. J. Am. Chem. Soc. 2007, 129, 12112-12113. [CrossRef] 
67. Viedma, C.; Cintas, P. On the chiral homogeneity of nature: From atoms to small molecules. Isr. J. Chem. 2011, 51, 997-1006. [CrossRef]

68. Mastai, Y.; Volkel, A.; Colfen, H. Separation of racemate from excess enantiomer of chiral nonracemic compounds via density gradient ultracentrifugation. J. Am. Chem. Soc. 2008, 130, 2426-2427. [CrossRef]

69. Kozma, D.; Kassai, C.; Fogassy, E. Enantiomeric enrichment by the use of density differences between racemic compounds and optically active enantiomers. Tetrahedron Lett. 1995, 36, 3245-3246. [CrossRef]

70. Yang, X.; Wong, S.Y.; Bwambok, D.K.; Atkinson, M.B.J.; Zhang, X.; Whitesides, G.M.; Myerson, A.S. Separation and enrichment of enantiopure from racemic compounds using magnetic levitation. Chem. Commun. 2014, 50, 7548-7551. [CrossRef]

71. Han, J.; Soloshonok, V.A.; Klika, K.D.; Drabowicz, J.; Wzorek, A. Chiral sulfoxides: Advances in asymmetric synthesis and problems with the accurate determination of the stereochemical outcome. Chem. Soc. Rev. 2018, 47, 1307-1350. [CrossRef]

72. Bánhegyi, D.F.; Pálovics, E. The stoichiometry, structure and possible formation of crystalline diastereomeric salts. Symmetry 2021, 13, 667. [CrossRef]

73. Schurig, V. Elaborate treatment of retention in chemoselective chromatography-The retention increment approach and nonlinear effects. J. Chromatogr. A 2009, 1216, 1723-1736. [CrossRef]

74. Jung, M.; Schurig, V. Computer simulation of three scenarios for the separation of non-racemic mixtures by chromatography on achiral stationary phases. J. Chromatogr. 1992, 605, 161-166. [CrossRef]

75. Gil-Av, E.; Schurig, V. Resolution of non-racemic mixtures in achiral chromatographic systems: A model for the enantioselective effects observed. J. Chromatogr. A 1994, 666, 519-525. [CrossRef]

76. Baciocchi, R.; Zenoni, G.; Mazzotti, M.; Morbidelli, M. Separation of binaphthol enantiomers through achiral chromatography. J. Chromatogr. A 2002, 944, 225-240. [CrossRef]

77. Baciocchi, R.; Mazzotti, M.; Morbidelli, M. General model for the achiral chromatography of enantiomers forming dimers: Application to binaphthol. J. Chromatogr. A 2004, 1024, 15-20. [CrossRef]

78. Soloshonok, V.A.; Roussel, C.; Kitagawa, O.; Sorochinsky, A.E. Self-disproportionation of enantiomers via achiral chromatography: A warning and extra dimension in optical purifications. Chem. Soc. Rev. 2012, 41, 4180-4188. [CrossRef]

79. Carman, R.M.; Klika, K.D. Partially racemic compounds as brushtail possum urinary metabolites. Aust. J. Chem. 1992, 45, 651-657. [CrossRef]

80. Flynn, A.J.; Ford, A.; Maguire, A.R. Localized partitioning of enantiomers in solid samples of sulfoxides: Importance of sampling method in determination of enantiopurity. J. Org. Chem. 2020, 85, 10216-10221. [CrossRef]

81. Wzorek, A.; Sato, A.; Drabowicz, J.; Soloshonok, V.A. Self-disproportionation of enantiomers via achiral gravity-driven column chromatography: A case study of $N$-acyl- $\alpha$-phenylethylamines. J. Chromatogr. A 2016, 1467, 270-278. [CrossRef]

82. Terada, S.; Hirai, M.; Honzawa, A.; Kitagawa, O.; Kamizela, A.; Wzorek, A.; Soloshonok, V.A. Possible case of halogen bonddriven self-disproportionation of enantiomers (SDE) via achiral chromatography. Chem. Eur. J. 2017, 23, 14631-14638. [CrossRef] [PubMed]

83. Imai, T.; Niijima, E.; Terada, S.; Wzorek, A.; Soloshonok, V.A.; Horie, A.; Kitagawa, O. Chirality-dependent halogen bond in axially chiral quinazolin-4-one derivatives bearing ortho-halophenyl group. CrystEngComm 2019, 21, 3385-3389. [CrossRef]

84. Takahashi, M.; Tanabe, H.; Nakamura, T.; Kuribara, D.; Yamazaki, T.; Kitagawa, O. Atropisomeric lactam chemistry: Catalytic enantioselective synthesis, application to asymmetric enolate chemistry and synthesis of key intermediates for NET inhibitors. Tetrahedron 2010, 66, 288-296. [CrossRef]

85. Wzorek, A.; Klika, K.D.; Drabowicz, J.; Sato, A.; Aceña, J.L.; Soloshonok, V.A. The self-disproportionation of the enantiomers (SDE) of methyl $n$-pentyl sulfoxide via achiral, gravity-driven column chromatography: A case study. Org. Biomol. Chem. 2014, 12, 4738-4746. [CrossRef]

86. Soloshonok, V.A.; Berbasov, D.O. Self-disproportionation of enantiomers on achiral phase chromatography. One more example of fluorine's magic powers. Chim. Oggi Chem. Today 2006, 24, 44-47.

87. Sorochinsky, A.E.; Aceña, J.L.; Soloshonok, V.A. Self-disproportionation of enantiomers of chiral, non-racemic fluoroorganic compounds: Role of fluorine as enabling element. Synthesis 2013, 45, 141-152. [CrossRef]

88. Yasumoto, M.; Ueki, H.; Soloshonok, V.A. Self-disproportionation of enantiomers of 3,3,3-trifluorolactic acid amides via sublimation. J. Fluorine Chem. 2010, 131, 266-269. [CrossRef]

89. Yasumoto, M.; Ueki, H.; Soloshonok, V.A. Self-disproportionation of enantiomers of $\alpha$-trifluoromethyl lactic acid amides via sublimation. J. Fluorine Chem. 2010, 131, 540-544. [CrossRef]

90. Mei, H.; Han, J.; Fustero, S.; Medio-Simon, M.; Sedgwick, D.M.; Santi, C.; Ruzziconi, R.; Soloshonok, V.A. Fluorine-containing drugs approved by the FDA in 2018. Chem. Eur. J. 2019, 25, 11797-11819. [CrossRef]

91. Mei, H.; Remete, A.M.; Zou, Y.; Moriwaki, H.; Fustero, S.; Kiss, L.; Soloshonok, V.A.; Han, J. Fluorine-containing drugs approved by the FDA in 2019. Chin. Chem. Lett. 2020, 31, 2401-2413. [CrossRef]

92. Zhu, W.; Wang, J.; Wang, S.; Gu, Z.; Aceña, J.L.; Izawa, K.; Liu, H.; Soloshonok, V.A. Recent advances in the trifluoromethylation methodology and new $\mathrm{CF}_{3}$-containing drugs. J. Fluorine Chem. 2014, 167, 37-54. [CrossRef]

93. Han, J.; Kiss, L.; Mei, H.; Remete, A.M.; Ponikvar-Svet, M.; Sedgwick, D.M.; Roman, R.; Fustero, S.; Moriwaki, H.; Soloshonok, V.A. Chemical aspects of human and environmental overload with fluorine. Chem. Rev. 2021, 121, 4678-4742. [CrossRef]

94. Mei, H.; Han, J.; White, S.; Graham, D.J.; Izawa, K.; Sato, T.; Fustero, S.; Meanwell, N.A.; Soloshonok, V.A. Tailor-made amino acids and fluorinated motifs as prominent traits in the modern pharmaceuticals. Chem. Eur. J. 2020, 26, 11349-11390. [CrossRef] 
95. Mei, H.; Han, J.; Klika, K.D.; Izawa, K.; Sato, T.; Meanwell, N.A.; Soloshonok, V.A. Applications of fluorine-containing amino acids for drug design. Eur. J. Med. Chem. 2020, 186, 111826. [CrossRef] [PubMed]

96. Han, J.; Remete, A.M.; Dobson, L.S.; Kiss, L.; Izawa, K.; Moriwaki, H.; Soloshonok, V.A.; O’Hagan, D. Next generation organofluorine containing blockbuster drugs. J. Fluorine Chem. 2020, 239, 109639. [CrossRef]

97. Fujiwara, T.; O'Hagan, D. Successful fluorine-containing herbicide agrochemicals. J. Fluorine Chem. 2014, 167, 16-29. [CrossRef]

98. Jeschke, P. The unique role of halogen substituents in the design of modern agrochemicals. Pest Manag. Sci. 2010, 66, 10-27. [CrossRef] [PubMed]

99. Jeschke, P. The unique role of fluorine in the design of active ingredients for modern crop protection. ChemBioChem 2004, 5, 570-589. [CrossRef]

100. Jeschke, P. Latest Generation of Halogen-Containing Pesticides. Pest Manag. Sci. 2017, 73, 1053-1066. [CrossRef]

101. Bravo, P.; Guidetti, M.; Viani, F.; Zanda, M.; Markovsky, A.L.; Sorochinsky, A.E.; Soloshonok, I.V.; Soloshonok, V.A. Chiral sulfoxide controlled asymmetric additions to $\mathrm{CN}$ double bond. An efficient approach to stereochemically defined $\alpha$-fluoroalkyl amino compounds. Tetrahedron 1998, 54, 12789-12806. [CrossRef]

102. Drabowicz, J.; Jasiak, A.; Wzorek, A.; Sato, A.; Soloshonok, V.A. Self-disproportionation of enantiomers (SDE) of chiral sulfoxides, amides and thioamides via achiral chromatography. Arkivoc 2017, 2017, 557-578. [CrossRef]

103. Richardson, P.; Hawkey, C.J.; Stack, W.A. Proton pump inhibitors. Pharmacology and rationale for use in gastrointestinal disorders. Drugs 1998, 56, 307-335. [CrossRef]

104. Wzorek, A.; Kamizela, A.; Sato, A.; Soloshonok, V.A. Self-disproportionation of enantiomers (SDE) via achiral gravity-driven column chromatography of $\mathrm{N}$-fluoroacyl-1-phenylethylamines. J. Fluorine Chem. 2017, 196, 37-43. [CrossRef]

105. Han, J.; Wzorek, A.; Kwiatkowska, M.; Soloshonok, V.A.; Klika, K.D. The self-disproportionation of enantiomers (SDE) of amino acids and their derivatives. Amino Acids 2019, 51, 865-889. [CrossRef]

106. Soloshonok, V.A.; Izawa, K. Asymmetric Synthesis and Application of Alpha-Amino Acids; Oxford University Press: Oxford, UK, 2009.

107. Liu, J.; Han, J.; Izawa, K.; Sato, T.; White, S.; Meanwell, N.A.; Soloshonok, V.A. Cyclic tailor-made amino acids in the design of modern pharmaceuticals. Eur. J. Med. Chem. 2020, 208, 112736. [CrossRef] [PubMed]

108. Han, J.; Konno, H.; Sato, T.; Soloshonok, V.A.; Izawa, K. Tailor-made amino acids in the design of small-molecule blockbuster drug. Eur. J. Med. Chem. 2021, 220, 113448. [CrossRef]

109. Yin, Z.; Hu, W.; Zhang, W.; Konno, H.; Moriwaki, H.; Izawa, K.; Soloshonok, V.A.; Han, J. Tailor-made amino acid-derived pharmaceuticals approved by the FDA in 2019. Amino Acids 2020, 52, 1227-1261. [CrossRef] [PubMed]

110. Takeda, R.; Kawamura, A.; Kawashima, A.; Sato, T.; Moriwaki, H.; Izawa, K.; Akaji, K.; Wang, S.; Liu, H.; Aceña, J.L.; et al. Chemical dynamic kinetic resolution and $(S) /(R)$-interconversion of unprotected $\alpha$-amino acids. Angew. Chem. Int. Ed. 2014, 53, 12214-12217. [CrossRef] [PubMed]

111. Qiu, W.; Gu, X.; Soloshonok, V.A.; Carducci, M.D.; Hruby, V.J. Stereoselective synthesis of conformationally constrained reverse turn dipeptide mimetics. Tetrahedron Lett. 2001, 42, 145-148. [CrossRef]

112. Klika, K.D.; Budovská, M.; Kutschy, P. Enantiodifferentiation of phytoalexin spirobrassinin derivatives using the chiral solvating agent $(R)-(+)-1,1^{\prime}$-bi-2-naphthol in conjunction with molecular modeling. Tetrahedron Asymmetry 2010, 21, 647-658. [CrossRef]

113. Nakajima, M.; Kanayama, K.; Miyoshi, I.; Hashimoto, S.-I. Catalytic asymmetric synthesis of binaphthol derivatives by aerobic oxidative coupling of 3-Hydroxy-2-naphthoates with chiral diamine-copper complex. Tetrahedron Lett. 1995, 36, 9519-9520. [CrossRef]

114. Nakajima, M.; Miyoshi, I.; Kanayama, K.; Hashimoto, S.-I.; Noji, M.; Koga, K. Enantioselective synthesis of binaphthol derivatives by oxidative coupling of naphthol derivatives catalyzed by chiral diamine copper complexes. J. Org. Chem. 1999, 64, $2264-2271$. [CrossRef]

115. Nieminen, V.; Murzin, D.Y.; Klika, K.D. NMR and molecular modeling of the dimeric self-association of the enantiomers of 1,1'bi-2-naphthol and 1-phenyl-2,2,2-trifluoroethanol in the solution state and their relevance to enantiomer self-disproportionation on achiral-phase chromatography (ESDAC). Org. Biomol. Chem. 2009, 7, 537-542. [CrossRef]

116. Baciocchi, R.; Zenoni, G.; Valentini, M.; Mazzotti, M.; Morbidelli, M. Measurement of the dimerization equilibrium constants of enantiomers. J. Phys. Chem. A 2002, 106, 10461-10469. [CrossRef]

117. Brussee, J.; Jansen, A.C.A. A highly stereoselective synthesis of S-(-)-[1,1'-binaphthalene]-2,2'-diol. Tetrahedron Lett. 1983, 24, 3261-3262. [CrossRef]

118. Ishii, A.; Soloshonok, V.A.; Mikami, K. Asymmetric catalysis of the friedel-crafts reaction with fluoral by chiral binaphthol-derived titanium catalysts through asymmetric activation. J. Org. Chem. 2000, 65, 1597-1599. [CrossRef] [PubMed]

119. Girard, C.; Kagan, H.B. Nonlinear effects in asymmetric synthesis and stereoselective reactions: Ten years of investigation. Angew. Chem. Int. Ed. 1998, 37, 2922-2959. [CrossRef]

120. Girard, C.; Kagan, H.B. On diastereomeric perturbations. Can. J. Chem. 2000, 78, 816-828. [CrossRef]

121. Noyori, R.; Suga, S.; Oka, H.; Kitamura, M. Self and nonself recognition of chiral catalysts: The origin of nonlinear effects in the amino-alcohol catalyzed asymmetric addition of diorganozincs to aldehydes. Chem. Rec. 2001, 1, 85-100. [CrossRef] [PubMed]

122. Martens, J.; Bhushan, R. Resolution of enantiomers with achiral phase chromatography. J. Liq. Chromatogr. Relat. Technol. 1992, 15, 1-27. [CrossRef] 
123. Han, J.; Wzorek, A.; Klika, K.D.; Soloshonok, V.A. Fluorine-Containing Pharmaceuticals and the Phenomenon of the SelfDisproportionation of Enantiomers in Late-Stage Fluorination of Bioactive Molecules and Biologically-Relevant Substrates; Postigo, A., Ed.; Elsevier: Amsterdam, The Netherlands, 2018; pp. 321-355.

124. Han, J.; Wzorek, A.; Klika, K.D.; Soloshonok, V.A. The Role of Fluorine in the Self-Disproportionation of Enantiomers (SDE) Phenomenon of Scalemic Samples of Fluoroorganics in Frontiers of Organofluorine Chemistry; Ojima, I., Ed.; World Scientific Publishing Co.: London, UK, 2020; pp. 283-340.

125. Han, J.; Fustero, S.; Moriwaki, H.; Wzorek, A.; Soloshonok, V.A.; Klika, K.D. The self-disproportionation of enantiomers (SDE): Fluorine as an SDE-phoric substituent. In Organofluorine Chemistry: Synthesis, Modeling, and Applications; Szabó, K.J., Selander, N., Eds.; Wiley-VCH: Weinheim, Germany, 2021; pp. 281-306.

126. Wzorek, A.; Sato, A.; Drabowicz, J.; Soloshonok, V.A. Self-disproportionation of enantiomers (SDE) of chiral nonracemic amides via achiral chromatography. Isr. J. Chem. 2016, 56, 977-989. [CrossRef]

127. Pracejus, G. Optische aktivierung von N-Phthalyl- $\alpha$-aminosäure-derivaten durch tert-basen-katalyse. Liebigs Ann. Chem. 1959, 622, 10-22. [CrossRef]

128. Kwart, H.; Hoster, D.P. Separation of an enantiomorph and its racemate by sublimation. J. Org. Chem. 1967, 32, 1867-1870. [CrossRef]

129. Garin, D.L.; Cooke Greco, D.J.; Kelly, L. Enhancement of optical activity by fractional sublimation. An alternative to fractional crystallization and a warning. J. Org. Chem. 1977, 42, 1249-1251. [CrossRef]

130. Tsuzuki, S.; Orita, H.; Ueki, H.; Soloshonok, V.A. First principle lattice energy calculations for enantiopure and racemic crystals of $\alpha$-(trifluoromethyl)lactic acid: Is self-disproportionation of enantiomers controlled by thermodynamic stability of crystals? J. Fluorine Chem. 2010, 131, 461-466. [CrossRef]

131. Tonner, R.; Soloshonok, V.A.; Schwerdtfeger, P. Theoretical investigations into the enantiomeric and racemic forms of $\alpha$ (trifluoromethyl)lactic acid. Phys. Chem. Chem. Phys. 2011, 13, 811-817. [CrossRef]

132. Wang, J.; Sánchez-Roselló, M.; Aceña, J.L.; del Pozo, C.; Sorochinsky, A.E.; Fustero, S.; Soloshonok, V.A.; Liu, H. Fluorine in pharmaceutical industry: Fluorine-containing drugs introduced to the market in the last decade (2001-2011). Chem. Rev. 2014, 114, 2432-2506. [CrossRef]

133. Zhou, Y.; Wang, J.; Gu, Z.; Wang, S.; Zhu, W.; Aceña, J.L.; Soloshonok, V.A.; Izawa, K.; Liu, H. Next generation of fluorinecontaining pharmaceuticals, compounds currently in phase II-III clinical trials of major pharmaceutical companies: New structural trends and therapeutic areas. Chem. Rev. 2016, 116, 422-518. [CrossRef] [PubMed]

134. Cundy, K.C.; Crooks, P.A. Unexpected phenomenon in the high-performance liquid chromatographic analysis of racemic ${ }^{14}$ C-labelled nicotine: Separation of enantiomers in a totally achiral system. J. Chromatogr. 1983, 281, 17-33. [CrossRef]

135. Reyes-Rangel, G.; Vargas-Caporali, J.; Juaristi, E. Asymmetric Michael addition reaction organocatalyzed by stereoisomeric pyrrolidine sulfinamides under neat conditions. A brief study of self-disproportionation of enantiomers. Tetrahedron 2017, 73 , 4707-4718. [CrossRef]

136. Li, J.; Mo, Y.; Yan, L.; Feng, X.; Su, Z.; Liu, X. Organocatalytic stereoselective [8+2] cycloaddition of tropones with azlactones. CCS Chem. 2021, 3, 784-793. [CrossRef]

137. Kotora, M.; Cadart, T.; Nečas, D.; Kaiser, R.P.; Favereau, L.; Císařová, I.; Gyepes, R.; Hodačová, J.; Kalíková, K.; Bednárová, L.; et al. Rhodium catalyzed enantioselective synthesis of highly fluorescent and CPL active Dispiroindeno[2,1-c]fluorenes. Chem. Eur. J. 2021. [CrossRef]

138. Robak, M.A.; Herbage, M.A.; Ellman, J.A. Synthesis and applications of tert-Butanesulfinamide. Chem. Rev. 2010, 110, 3600-3740. [CrossRef]

139. Fioravanti, S. Trifluoromethyl aldimines: An overview in the last ten years. Tetrahedron 2016, 72, 4449-4489. [CrossRef]

140. Mei, H.; Xie, C.; Han, J.; Soloshonok, V.A. N-tert-Butanesulfinyl-(3,3,3)-trifluoroacetaldimine: Versatile reagent for asymmetric synthesis of trifluoromethyl-containing amines and amino acids of pharmaceutical importance. Eur. J. Org. Chem. 2016, 2016, 5917-5932. [CrossRef]

141. Mei, H.; Han, J.; Fustero, S.; Román, R.; Ruzziconi, R.; Soloshonok, V.A. Recent progress in the application of fluorinated chiral sulfinimine reagents. J. Fluorine Chem. 2018, 216, 57-70. [CrossRef]

142. Agranat, I.; Caner, H. Intellectual property and chirality of drugs. Drug Discov. Today 1999, 4, 313-321. [CrossRef]

143. Bentley, R. Role of sulfur chirality in the chemical processes of biology. Chem. Soc. Rev. 2005, 34, 609-624. [CrossRef] [PubMed]

144. O'Mahony, G.E.; Kelly, P.; Lawrence, S.E.; Maguire, A.R. Synthesis of enantioenriched sulfoxides. Arkivoc 2011, 2011, 1-110. [CrossRef]

145. Wojaczynska, E.; Wojaczynski, J. Enantioselective synthesis of sulfoxides: 2000-2009. Chem. Rev. 2010, 110, 4303-4356. [CrossRef]

146. O'Mahony, G.E.; Ford, A.; Maguire, A.R. Asymmetric oxidation of sulfides. J. Sulfur Chem. 2013, 34, 301-341. [CrossRef]

147. Sipos, G.; Drinkel, E.E.; Dorta, R. The emergence of sulfoxides as efficient ligands in transition metal catalysis. Chem. Soc. Rev. 2015, 44, 3834-3860. [CrossRef]

148. Otocka, S.; Kwiatkowska, M.; Madalińska, L.; Kiełbasiński, P. Chiral organosulfur ligands/catalysts with a stereogenic sulfur atom: Applications in asymmetric synthesis. Chem. Rev. 2017, 117, 4147-4181. [CrossRef]

149. Brunel, J.-M.; Kagan, H.B. Catalytic enantioselective oxidation of sulfides with a chiral titanium complex. Bull. Soc. Chim. Fr. 1996, 133, 1109-1115.

150. Kagan, H.B.; Riant, O. Advances in Asymmetric Synthesis; Elsevier: Amsterdam, The Netherlands, 1997; Volume 2, pp. $189-235$. 
151. Brunel, J.-M.; Luukas, T.O.; Kagan, H.B. Nonlinear effects as 'indicators' in the tuning of asymmetric catalysts. Tetrahedron Asymmetry 1998, 9, 1941-1946. [CrossRef]

152. Fenwick, D.R.; Kagan, H.B. Asymmetric amplification. In Top Stereochem; Denmark, S.E., Ed.; Wiley: Hoboken, NJ, USA, 1999; Volume 22, pp. 257-296.

153. Mata, E.G. Recent advances in the synthesis of sulfoxides from sulfides. Phosphorus Sulfur Silicon Relat. Elem. 1996, 117, $231-286$. [CrossRef]

154. Sun, J.; Zhu, C.; Dai, Z.; Yang, M.; Pan, Y.; Hu, H. Efficient asymmetric oxidation of sulfides and kinetic resolution of sulfoxides catalyzed by a vanadium-salan system. J. Org. Chem. 2004, 69, 8500-8503. [CrossRef] [PubMed]

155. Sprout, C.M.; Seto, C.T. Using enzyme inhibition as a high throughput method to measure the enantiomeric excess of a chiral sulfoxide. Org. Lett. 2005, 7, 5099-5102. [CrossRef]

156. Legros, J.; Bolm, C. Investigations on the iron-catalyzed asymmetric sulfide oxidation. Chem. Eur. J. 2005, 11, 1086-1092. [CrossRef]

157. Tanaka, H.; Nishikawa, H.; Uchida, T.; Katsuki, T. Photopromoted ru-catalyzed asymmetric aerobic sulfide oxidation and epoxidation using water as a proton transfer mediator. J. Am. Chem. Soc. 2010, 132, 12034-12041. [CrossRef]

158. Han, J.; Sorochinsky, A.E.; Ono, T.; Soloshonok, V.A. Biomimetic transamination-A metal-free alternative to the reductive amination. Application for generalized preparation of fluorine-containing amines and amino acids. Curr. Org. Synth. 2011, 8, 281-294. [CrossRef]

159. Soloshonok, V.A.; Ono, T.; Soloshonok, I.V. Enantioselective biomimetic transamination of $\beta$-Keto carboxylic acid derivatives. An efficient asymmetric synthesis of $\beta$-Fluoroalkyl- $\beta$-amino acids. J. Org. Chem. 1997, 62, 7538-7539. [CrossRef]

160. Soloshonok, V.A.; Kirilenko, A.G.; Fokina, N.A.; Galushko, S.V.; Kukhar, V.P.; Svedas, V.K.; Resnati, G. Chemo-enzymatic approach to the synthesis of each of the four isomers of $\alpha$-Alkyl- $\beta$-Fluoroalkyl-substituted $\beta$-amino acids. Tetrahedron Asymmetry 1994, 5, 1225-1228. [CrossRef]

161. Soloshonok, V.A.; Yasumoto, M. Catalytic asymmetric synthesis of $\alpha$-(Trifluoromethyl)benzylamine via cinchonidine derived base-catalyzed biomimetic 1,3-proton shift reaction. J. Fluorine Chem. 2007, 128, 170-173. [CrossRef]

162. Soloshonok, V.A.; Kirilenko, A.G.; Galushko, S.V.; Kukhar, V.P. Catalytic asymmetric synthesis of $\beta$-Fluoroalkyl- $\beta$-amino acids via biomimetic [1,3]-proton shift reaction. Tetrahedron Lett. 1994, 35, 5063-5064. [CrossRef]

163. Soloshonok, V.A.; Kukhar, V.P. Biomimetic transamination of $\alpha$-Keto perfluorocarboxylic esters. An efficient preparative synthesis of $\beta, \beta, \beta$-Trifluoroalanine. Tetrahedron 1997, 53, 8307-8314. [CrossRef]

164. Soloshonok, V.A.; Gerus, I.I.; Yagupolskii, Y.L.; Kukhar, V.P. Fluorine-containing amino acids. III. $\alpha$-Trifluoromethyl amino acids. Zh. Org. Khim. 1987, 23, 2308-2313.

165. Soloshonok, V.A.; Kirilenko, A.G.; Kukhar, V.P.; Resnati, G. Transamination of fluorinated $\beta$-Keto carboxylic esters. A biomimetic approach to $\beta$-Polyfluoroalkyl- $\beta$-amino acids. Tetrahedron Lett. 1993, 34, 3621-3624. [CrossRef]

166. Soloshonok, V.A.; Kukhar, V.P. Biomimetic base-catalyzed [1,3]-proton shift reaction. A practical synthesis of $\beta$-Fluoroalkyl- $\beta$ amino acids. Tetrahedron 1996, 52, 6953-6964. [CrossRef]

167. Zhu, Y.; Mao, Y.; Mei, H.; Pan, Y.; Han, J.; Soloshonok, V.A.; Hayashi, T. Palladium-catalyzed asymmetric allylic alkylations of colby pro-enolates with MBH carbonates: Enantioselective access to quaternary C-F oxindoles. Chem. Eur. J. 2018, 24, 8994-8998. [CrossRef] [PubMed]

168. Sha, W.; Zhu, Y.; Mei, H.; Han, J.; Soloshonok, V.A.; Pan, Y. Catalytic enantioselective cyano-trifluoromethylation of styrenes. ChemistrySelect 2017, 2, 1129-1132. [CrossRef]

169. Zhang, L.; Zhang, W.; Mei, H.; Han, J.; Soloshonok, V.A.; Pan, Y. Catalytic asymmetric aldol addition reactions of 3-fluoroindolinone derived enolates. Org. Biomol. Chem. 2017, 15, 311-315. [CrossRef] [PubMed]

170. Zhu, Y.; Zhang, W.; Mei, H.; Han, J.; Soloshonok, V.A.; Pan, Y. Catalytic enantioselective Michael addition reactions of tertiary enolates generated by detrifluoroacetylation. Chem. Eur. J. 2017, 23, 11221-11225. [CrossRef] [PubMed]

171. Zhang, L.; Xie, C.; Dai, Y.; Mei, H.; Han, J.; Soloshonok, V.A.; Pan, Y. Catalytic asymmetric detrifluoroacetylative aldol reactions of aliphatic aldehydes for construction of C-F quaternary stereogenic centers. J. Fluorine Chem. 2016, 184, 28-35. [CrossRef]

172. Sha, W.; Zhang, W.; Mei, H.; Soloshonok, V.A.; Han, J.; Pan, Y. Catalytic cascade aldol-cyclization of tertiary ketone enolates for enantioselective synthesis of keto-esters with a C-F quaternary stereogenic center. Org. Biomol. Chem. 2016, 14, 7295-7303. [CrossRef]

173. Xie, C.; Wu, L.; Han, J.; Soloshonok, V.A.; Pan, Y. Assembly of fluorinated quaternary stereogenic centers via catalytic enantioselective detrifluoroacetylative aldol reactions. Angew. Chem. Int. Ed. 2015, 54, 6019-6023. [CrossRef]

174. Soloshonok, V.A.; Wzorek, A.; Klika, K.D. A question of policy: Should tests for the self-disproportionation of enantiomers (SDE) be mandatory for reports involving scalemates? Tetrahedron Asymmetry 2017, 28, 1430-1434. [CrossRef]

175. Zhang, L.; Zhang, W.; Sha, W.; Mei, H.; Han, J.; Soloshonok, V.A. Detrifluoroacetylative generation and chemistry of fluorine containing tertiary enolates. J. Fluorine Chem. 2017, 198, 2-9. [CrossRef]

176. Shibatomi, K.; Narayama, A.; Abe, Y.; Iwasa, S. Practical synthesis of 4,4,4-trifluorocrotonaldehyde: A versatile precursor for the enantioselective formation of trifluoromethylated stereogenic centers via organocatalytic 1,4-additions. Chem. Commun. 2012, 48, 7380-7382. [CrossRef]

177. Shibatomi, K.; Narayama, A.; Soga, Y.; Muto, T.; Iwasa, S. Enantioselective gem-chlorofluorination of active methylene compounds using a chiral spiro oxazoline ligand. Org. Lett. 2011, 13, 2944-2947. [CrossRef] 
178. Shibatomi, K.; Soga, Y.; Narayama, A.; Fujisawa, I.; Iwasa, S. Highly enantioselective chlorination of $\beta$-Keto esters and subsequent $\mathrm{S}_{\mathrm{N}} 2$ displacement of tertiary chlorides: A flexible method for the construction of quaternary stereogenic centers. J. Am. Chem. Soc. 2012, 134, 9836-9839. [CrossRef]

179. Shibatomi, K.; Futatsugi, K.; Kobayashi, F.; Iwasa, S.; Yamamoto, H. Stereoselective construction of halogenated quaternary stereogenic centers via catalytic asymmetric diels-alder reaction. J. Am. Chem. Soc. 2010, 132, 5625-5627. [CrossRef]

180. Huang, G.; Yang, J.; Zhang, X. Highly enantioselective zinc/BINOL-catalyzed alkynylation of $\alpha$-ketoimine ester: A new entry to optically active quaternary $\alpha-\mathrm{CF}_{3} \alpha$-amino acids. Chem. Commun. 2011, 47, 5587-5589. [CrossRef] [PubMed]

181. Walęcka-Kurczyk, A.; Walczak, K.; Kuźnik, A.; Stecko, S.; Październiok-Holewa, A. The synthesis of $\alpha$-Aminophosphonates via enantioselective organocatalytic reaction of 1-(N-Acylamino)alkylphosphonium salts with dimethyl phosphite. Molecules 2020, 25, 405. [CrossRef] [PubMed] 